\title{
Evolution of sandstone peak-forest landscapes - insights from quantifying erosional processes with cosmogenic nuclides
}

\author{
May, Jan-Hendrik ${ }^{1,2^{*}}$ \\ Huang, He-Qing ${ }^{3^{*}}$ \\ Fujioka, Toshiyuki ${ }^{4}$ \\ Fink, David ${ }^{4}$ \\ Codilean, Alexandru ${ }^{5}$ \\ $\mathrm{Yu}, \mathrm{Guo}-\mathrm{An}^{3}$ \\ Ma, Yuanxu ${ }^{6}$ \\ Wulf, Gerwin ${ }^{1}$ \\ Gu, Jing ${ }^{3}$ \\ 1 - Institute of Earth and Environmental Sciences, University of Freiburg, 79104 Freiburg, Germany \\ 2 - School of Geography, University of Melbourne, Carlton, VIC 3053, Australia \\ 3 - Key Laboratory Of Water Cycle and Related Land Surface Processes, Institute of Geographic Sciences and \\ Natural Resources Research, 11A Datun Road, Chaoyang District, Beijing, 100101, China \\ 4 - Australian Nuclear Science and Technology Organisation, Menai, NSW 2234, Australia \\ 5 - School of Earth and Environmental Sciences, University of Wollongong, Wollongong, NSW 2522, Australia \\ 6 - Institute of Remote Sensing and Digital Earth, Chinese Academy of Sciences, Haidian District, Beijing, \\ 100094, China \\ ${ }^{*}$ Correspondence to: Jan-Hendrik May, School of Geography, University of Melbourne, Carlton, VIC 3053, \\ Australia, E-mail: janhendrikmay@gmail.com; Professor He Qing Huang, Institute of Geographic Sciences and \\ Natural Resources Research, Chinese Academy of Sciences, 11A Datun Road, Chaoyang, E-mail: \\ huanghq@igsnrr.ac.cn
}

\section{Abstract}

The sandstone peak-forest landscape in Zhangjiajie UNESCO Global Geopark of Hunan Province, China, is characterized by $>3000$ vertical pillars and peak walls of up to $350 \mathrm{~m}$ height, representing a spectacular example of sandstone landform variety. Few studies have addressed the mechanisms and timescales of the longerterm evolution of this landscape, and have focused on fluvial incision. We use in-situ cosmogenic nuclides combined with GIS analysis to investigate the erosional processes contributing to the formation of pillars and peak-forests, and discuss their relative roles in the formation and decay of the landscape. Model maximum-limiting hedrock erosion rates are the highest along the narrow fluvial changels and valleys at

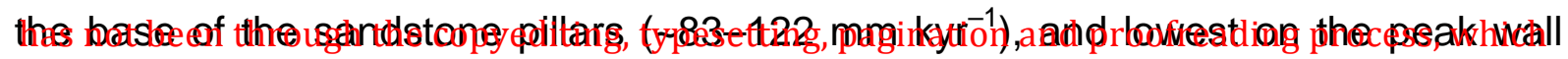

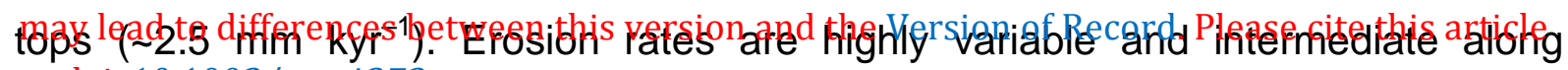

vertical sandstone peak walls and pillars $\left(-30\right.$ to $\left.84 \mathrm{~mm} \mathrm{kyr}^{-1}\right)$. Catchment-wide 
denudation rates from river sediment vary between $\sim 26$ and $96 \mathrm{~mm} \mathrm{kyr}{ }^{-1}$ and are generally consistent with vertical wall retreat rates. This highlights the importance of wall retreat for overall erosion in the sandstone peak-forest. In combination with GISderived erosional volumes, our results suggest that the peak-forest formation in Zhangjiajie commenced in the Pliocene, and that the general evolution of the landscape followed our sequential refined model: (i) slow lowering rates following initial uplift, (ii) fast plateau dissection by headward knickpoint propagation along joints and faults followed by (iii) increasing contribution of wall retreat in the welldeveloped pillars and peak-forests and a gradual decrease in overall denudation rates, leading to (iv) the final consumption of pillars and peak-forests. Our study provides an approach for quantifying the complex interplay between multiple geomorphic processes as required to assess the evolutionary pathways of other sandstone peak-forest landscapes across the globe.

\section{Keywords}

Sandstone, peak-forest, landscape evolution, cosmogenic nuclides, erosion 


\section{Introduction}

Sandstone landscapes around the world exhibit a surprising variety in terms of their geomorphology and formative processes. Particular attention has recently been given to macro-scale landforms such as sandstone tower karst and peak-forest assemblages (Young et al., 2009; Wray, 2013; Migoń et al., 2017). These spectacular landscapes have gained enormous touristic and economic value (Zhao and Wang, 2002; Brierley et al., 2011; Yao and Yin, 2011) and reflect a wide range of controls that dominate the weathering and erosion of sandstone on various spatial scales (Young et al., 2009). Locally, lithological, sedimentary and structural characteristics determine the mechanical rock strength and susceptibility for physical weathering, while the elemental and mineralogical composition of the sandstone in combination with the prevailing climate affect the intensity and efficiency of chemical weathering (Young and Wray, 2015). In addition, climatic changes inevitably change the relative contributions and types of physical and chemical processes on various Cenozoic time scales. Finally, long-term variations in regional tectonic activity exert a strong influence on the generation of topography as required for the evolution of erosional landscapes. This interplay of internal and external controls on landscape development thus introduces considerable natural variety and complexity to sandstone landscapes which has triggered ongoing discussions on the uniqueness of particular regional sandstone landscapes and their geomorphic classification and labelling (Chen and Xie, 1994; Zhou et al., 2004; Brierley et al., 2011). In combination with our still limited understanding of the longer-term evolution of sandstone landscapes this emphasizes the need for more detailed and quantified data on the various geomorphic processes that contribute to the formation of sandstone landforms in general.

A particularly spectacular example of a sandstone peak-forest with more than 3000 sheer vertical pillars, towers, peaks and walls of up to $350 \mathrm{~m}$ height is located in Zhangjiajie UNESCO Global Geopark, which covers the whole Wulingyuan District of Zhangjiajie City in the western Hunan Province of China (Fig. 1a). The unique geomorphic character of the area has been prominently marketed (Hong, 2011; Yao and Yin, 2011) and declared an UNESCO Natural Heritage Site and a Global Geopark (Zhao and Wang, 2002; Zhao et al., 2011). However, little data exist 
regarding the formation and evolution of the spectacular landscapes as the region has come to attention only in late 1979 and very limited research has been conducted since then.

[Fig. 1]

Early studies have mainly highlighted their scenic value based on the description of typical landforms (Chen, 1993; Chen and Xie, 1994; Wu and Zhang, 2002). More recent investigations focused on the detailed analyses of weathering profiles ( $\mathrm{Ni}$ et al., 2011), lithological and mineralogical characteristics (Huang et al., 2006), and the interpretation of remote sensing data ( $\mathrm{Hu}, 2011$; Yang et al., 2011a; Yang et al., 2012). Only a few studies have addressed questions regarding the temporal evolution of the landscapes. The first chronological model for landscape evolution in Zhangjiajie Global Geopark is based on ESR and TL dating of terrace staircases and sediments from multi-storey cave systems in adjacent limestone areas, and suggests an early to mid-Pleistocene onset of sandstone peak-forest formation triggered by fluvially driven incision into the heavily jointed and fractured quartzitic sandstone (Yang et al., 2010; Ping et al., 2011; Yang et al., 2011b). Detailed analyses of river long-profiles combined with the few chronological data are generally consistent with these results (Shi and Qi, 2013; Shi and Shao, 2014). Through this focus on fluvial processes, however, most existing studies have paid less attention to erosional processes such as physical weathering and mass-wasting along the vertical sandstone walls, or downwearing of the hillslopes and peak tops, raising the question regarding their significance for the erosional history in these landscapes.

Over the last few decades, cosmogenic nuclides have become an indispensable tool for the quantification of erosional processes on local and basin-wide scales (Dunai, 2010; Granger and Schaller, 2014; von Blanckenburg and Willenbring, 2014). A combined approach evaluating both fluvial and erosional processes holds high potential towards the establishment of a more complete picture of the sandstone peak-forest formation in Zhangjiajie and similar landscapes elsewhere.

In this study, we utilise the in-situ cosmogenic nuclide method to investigate a wider range of erosional processes and their controls which underlie the development of 
the sandstone peak-forest landscape in the upper catchment of the Suoxi River at Zhangjiajie. We approach this by providing rates of catchment-wide denudation, retreat of the vertical sandstone walls and peak tops, and fluvial bedrock incision via cosmogenic ${ }^{10} \mathrm{Be}$ measurements. We then discuss the relative roles of fluvial, masswasting and weathering processes in the long-term erosional history of the peakforest landscape. Further, we use the derived denudation rates in combination with field measurements and the GIS-based analysis of digital elevation models (DEMs) to quantify the total erosion volumes and their corresponding timescales since the onset of the peak-forest formation.

\section{Regional Setting of study area}

The sandstone peak-forest exhibited in Zhangjiajie Global Geopark (total area of 398 $\mathrm{km}^{2}$ ) is located in the northwestern corner of Hunan Province, China and belongs to the upper catchment of the Suoxi River, a fourth order tributary of the Yangtze River (Fig. 1a). This area ranges in elevation between $\sim 345 \mathrm{~m}$ asl and $\sim 1300 \mathrm{~m}$ asl at Tianzi Mountain (Fig. 1b). Today, climate in the region is subtropical and humid (Cfa climate; Peel et al., 2007) with an average annual precipitation of $\sim 1400-1600 \mathrm{~mm}$ strongly influenced by the Indian and East Asian Monsoon system (Clift and Plumb, 2008). The average annual temperature is $\sim 16^{\circ} \mathrm{C}$ but cold surges from the north can lead to severe frost and snow in winter. The region is mainly covered by deciduous and evergreen broad-leaf forest, bamboo forest, and evergreen coniferous forest (Qi et al., 1989) with interspersed agricultural land around small villages. With an increasing population size and intensified land use, the area has undergone dynamic changes over the last decades (Pang et al., 2013). The sediment yield at Shimen station, $\sim 100 \mathrm{~km}$ downstream of the study area and below the confluence of the tributary Suoxi River with the mainstream Lishui River, has markedly decreased from $7.17 \times 10^{6} \mathrm{t}(1954-1985)$ to $1.31 \times 10^{6} \mathrm{t}$ (2007-2011), accompanied by a minor decrease in the annual runoff from 15.2 to $13.6 \times 10^{9} \mathrm{~m}^{3}$ in the same period (Zheng, 2014). A small reservoir installed at Wulingyuan Town in the 1980 s holds an artificial lake and other minor weirs and dams are visible throughout the upper Suoxi catchment (Fig. S1a). 
Geologically, the area belongs to the Yangtze Block, which itself is an essential part of the South China continental block with a complex tectonic history $\mathrm{Wu}, 2005$; Wang et al., 2013; Zheng et al., 2013). The region around Zhangjiajie has undergone several periods of tectonic deformation and compression with an unconformity between the fine-grained sandstones of the Middle Silurian Formations and Devonian strata as evidence for erosion during the "Kwangsian" (or "Caledonian") orogeny. Subsequently, deposition in a shallow-marine environment built up the $\sim 520 \mathrm{~m}$ thick Middle Devonian Yuntaiguan Formation (D2yn) which consists of grayish to pink, fine-grained quartzitic sandstone with thin interbedded siltstones and muddy siltstones (Fig. 2). This formation is overlain by $\sim 5-41 \mathrm{~m}$ of fine-grained ferruginous quartz sandstone and thin but highly resistant layers of oolithic hematite belonging to the Upper Devonian Huangjiadeng Formation (D3h; Fig. 2) (Yang et al., 2010). A weakly developed unconformity and the absence of Carboniferous strata testify to renewed Hercynian tectonic movements before the deposition of thick strata of limestone summarized in various Permian (P1q, P2m) or Triassic formations (Fig. 2). These marine depositional episodes ended with uplift, extrusion, gentle folding and the formation of a NNW-ENE oriented network of joints and fractures during the Indosinian tectonic event ( 260-200 Ma) (Wan, 2012). This event was followed by strong E-W compression, reactivation of joints, and fracturing and folding during the Yanshanian and possibly Sichuanian events ( 200-56 Ma) (Wan, 2012; Yang et al., 2012), ultimately leading to the formation of the complex and dense network of joints and fractures as well the existence of superimposed anti- and synclines characterizing geological structure in the region.

[Fig. 2]

Relatively little is known with regard to the Cenozoic history of the region. Tectonically stable conditions seem to have allowed for the formation of a widely recognized planation surface (P1) which is still topographically expressed by common peak heights in the area around 1100-1300 m asl (Wu and Zhang, 2002; Yang et al., 2010; Yang et al., 2012) (Figs. 2, 3a) and may be correlative to similar uplifted surfaces in the Three Gorges area along the middle reaches of the Yangtze (Li et al., 2001; Cui et al., 2002). The onset of the Himalayan orogeny in the Neogene led to surface uplift, denudation and karstification processes still expressed in the 
gentle karst morphology developed in the Permian limestones (Fig. 2, 3a). Under continued uplift, erosion was slowed by the resistant ferruginous quartz sandstone of the Huangjiadeng Formation forming an erosional surface (L1; Figs. 2 and $3 a, b$ ) at 850-1000 $\mathrm{m}$ asl in the vicinity of Tianzi Mountain (Wu and Zhang, 2002; Yang et al., 2010; Ping et al., 2011), leading to mesa-type morphology and extremely steep valley headwalls often characterized by waterfalls (Fig. 3a, b).

Below the L1 surface, the jointed and fractured quartzitic sandstone of the Yuntaiguan Formation (D2yn) has been dissected into a variety of sandstone landforms ranging from mesa-type square mountains and peak walls at higher elevations (Fig. 3a) to sandstone peak clusters and forests (Fig. 3c) as well as remnant and single peaks (Fig. 3d,e) lining the narrow bedrock channels and canyons at lower elevation (Yang et al., 2012) (Fig. 2). These landforms occupy $\sim 40 \%\left(\sim 36 \mathrm{~km}^{2}\right)$ in our study area (total catchment area above Wulingyuan Town $\sim 90 \mathrm{~km}^{2}$; Table 1). Over $\sim 2300$ individual pillars and peaks with heights between a few 10s of meters up to $>300 \mathrm{~m}$ have been mapped (Hu, 2011; Yang et al., 2011a).

[Fig. 3]

Methods

Field work

Field work comprised reconnaissance and mapping in three contrasting geomorphic settings within the sandstone pillar and peak-forest landscapes, viz. (a) plateau and mesa $>1000 \mathrm{~m}$ asl, (b) sandstone peak-forest, and (c) canyons and channel floors. Field mapping concentrated on the valley and canyon margins to check for the presence of colluvial material. Topographic profiles were measured with a TruPulse 360 laser rangefinder along the upper Suoxi River to determine valley width and colluvial cone areas at the foot of the sandstone towers and pillars. Our sampling strategy aimed to provide information representing all three geomorphic settings in order to quantify the spatial variability of erosional processes. Therefore, a total of ten bedrock samples, each weighing $\sim 350 \mathrm{~g}$ of the quartzitic sandstone, were taken for cosmogenic ${ }^{10} \mathrm{Be}$ analysis across the three contrasting geomorphic settings of the 
pillar and peak-forest landscapes (Fig. 2). There are two samples each at two locations from geomorphic setting (c) (i.e. along the narrow bedrock channels, ZGW1 to 4; Fig. S2a-g), five samples from two locations from setting (b) (i.e., on the vertical peak walls, ZGW-5 to 9; Fig. S2h-I), and one sample from setting (a) (i.e., the horizontal plateau top of the peak-forest walls, ZGW-12; Fig. S2m-n). More extensive sampling particularly for settings (a) and (b) was not available due the limited access of plateau-top bedrock and constraints in sampling at the required depth along the vertical walls, respectively. Vegetation cover and geometric shielding were recorded at each bedrock site. To determine catchment-wide denudation rates, samples of $\sim 500 \mathrm{~g}$ of sand and pebbles were taken from river bars at six localities in the upper Suoxi catchment upstream of Wulingyuan Town (ZGC-1 to 6; Fig. 2, Fig. S3a-i). We processed the sand-size fraction (212-500 $\mu \mathrm{m})$ for all 6 samples and in addition the pebble fraction for ZGC-1, in order to test for differences in denudation rates related to grain size.

GIS analysis of catchment topography and geology

A GIS environment was implemented to analyse the upper Suoxi River catchment upstream of Wulingyuan Town. ArcGIS 10.4 (ESRI, 2015) was used for geospatial analyses of digital elevation models (DEMs) and for digitizing already available published geological and geomorphological maps of the study area (Yang et al., 2010; Yang et al., 2012). Digital elevation data from the Shuttle Radar Topography Mission (SRTM; Farr et al., 2007; Jarvis et al., 2008) with a resolution of 1 arcsecond ( $\sim 30 \mathrm{~m}$ at the equator) were used to derive the total catchment areas upstream of Wulingyuan Town and also for the sub-catchment areas supplying river sediment to each sample point using the spatial analyst extension of ArcGIS. All sinks within the SRTM data set were removed to produce a DEM without depressions avoiding possible discontinuous drainage networks in the following processing steps. Flow direction and flow accumulation were then derived using the eight-direction (D8) flow model by Jenson and Domingue (1988). A stream network was derived by applying a threshold value to the accumulated flow per cell from higher elevation cells in order to be included in the stream system. With regard to the area of interest, all cells with upstream catchment areas $>0.675 \mathrm{~km}^{2}$ were found appropriate to show only major stream systems while maintaining clarity. The resulting digitally derived 
stream network was visually compared with the drainage network visible in highresolution satellite image data (e.g. GoogleEarth) and manually modified where particularly narrow valley cross sections were not captured by the resolution of the SRTM 1arc DEM. In addition, the watersheds and catchment areas of all subcatchments upstream of Wulingyuan Town were determined by combining the derived flow direction with the outlet points of the watersheds defined by the river sediment sample points (pour points). Topographic and morphometric parameters such as catchment area, mean and maximum elevation and total relief were derived for each sub-catchment with the zonal statistics tool. Slope in degrees was calculated with the spatial analyst extension and averaged over the study area and each subcatchment. The areas in each sub-catchment occupied by sandstone peak-forest landforms and each geological unit was determined by digitizing published geological and geomorphological maps (Yang et al., 2010; Yang et al., 2012) and performing zonal statistics on these data.

For each sub-catchment, average denudational thickness or depth below the erosional surface L1 (here defined as $950 \pm 25 \mathrm{~m}$ asl) was determined as an approximation of the overall erosion since the onset of the sandstone peak-forest formation (Amato et al., 2003). In the GIS, denudational depths are derived from the ratio of volumes and two-dimensional surface areas calculated with the surface volume tool below reference planes at 925 and $975 \mathrm{~m}$ asl, respectively. To account for potential errors introduced by the resolution of the SRTM 1arc DEM, all parameters were also derived from the SRTM 3arc (Jarvis et al., 2008), Aster GDEM v02 (NASA LP DAAC, 2016) and ALOS AW3D30 (Tadono et al., 2014) elevation models, and subsequently averaged. The final denudational depth for each subcatchment then represents the average between the results for both reference planes and thus accounts for spatial variation of the erosional surface L1.

\section{$\underline{\text { Cosmogenic Nuclide analysis }}$}

The bedrock and river sediment samples were processed for $\mathrm{AMS}{ }^{10} \mathrm{Be}$ analysis at the Australian Nuclear Science and Technology Organisation (ANSTO). Initial treatment by successive etching with hot phosphoric acid (Mifsud et al., 2013) was followed by a final clean with standard $\mathrm{HF} / \mathrm{HNO}_{3}$ methods to obtain pure quartz (Kohl 
and Nishiizumi, 1992). After adding $\sim 330 \mu \mathrm{g}$ of ${ }^{9} \mathrm{Be}$ carrier derived from dissolved beryl crystal, $\sim 10-60 \mathrm{~g}$ of the purified quartz were dissolved in concentrated HF and ${ }^{10} \mathrm{Be}$ was extracted using ion-chromatography methods (Child et al., 2000). The ${ }^{10} \mathrm{Be} /{ }^{9} \mathrm{Be}$ ratios were measured at the ANSTO ANTARES AMS Facility (Fink and Smith, 2007) and were normalised to the 2007 KNSTD standard KN-5-2 with a nominal ${ }^{10} \mathrm{Be} /{ }^{9} \mathrm{Be}$ ratio of $8.558 \times 10^{-12}$ (Nishiizumi et al., 2007). Two full procedural blanks prepared from the same ${ }^{9} \mathrm{Be}$ carrier above gave a final mean ${ }^{10} \mathrm{Be} /{ }^{9} \mathrm{Be}$ ratio of $(5.8 \pm 1.4) \times 10^{-15}\left(\mathrm{n}=5\right.$, mean of 2 targets). Blank corrected ${ }^{10} \mathrm{Be} /{ }^{9} \mathrm{Be}$ ratios ranged between $(30.7 \pm 1.8) \times 10^{-15}$ and $(2037.9 \pm 24.7) \times 10^{-15}$ (Table 2, 3). Analytical errors (including counting statistics, standard normalisation and blank corrections) ranged from 1.2 to $15.6 \%$. Errors for the final ${ }^{10} \mathrm{Be}$ concentrations (atoms $\mathrm{g}^{-1}$ ) for all samples were calculated by summing in quadrature the analytical error for the AMS measurement, $2 \%$ for standard reproducibility, and $1 \%$ for uncertainty in the Be spike concentration.

Model bedrock erosion rates were calculated using the CRONUS-Earth online calculators (version 2.3 - http://hess.ess.washington.edu; Balco et al., 2008) and are reported here using the time-independent Lal/Stone scaling scheme (Stone, 2000). Catchment wide denudation rates were calculated with the open source code CAIRN (Mudd et al., 2016) and do not consider areas characterized by limestone lithology. Catchment averaged nuclide production from neutrons and muons was calculated with the approximation of Braucher et al. (2011) and using a sea-level and highlatitude total ${ }^{10} \mathrm{Be}$ production rate of 4.3 atoms $\mathrm{g}^{-1} \mathrm{y}^{-1}$ (Mudd et al., 2016). Production rates for catchment wide denudation rates were calculated at every pixel using the SRTM 1arc DEM, with the time-independent Lal/Stone scaling scheme (Stone, 2000). Atmospheric pressure was calculated via interpolation from the NCEP2 reanalysis data (Compo et al., 2011). Topographic shielding was calculated from the same SRTM 1arc DEM using the method of Codilean (2006). All our calculations assumed $\mathrm{a}{ }^{10} \mathrm{Be}$ half-life of $1.387 \pm 0.012 \mathrm{Myr}$ (Chmeleff et al., 2010; Korschinek et al., 2010).

\section{Analysis and results}

\section{$\underline{\text { GIS analysis and geomorphology }}$}


The highest topographic elevations in the study area of $\sim 1260 \mathrm{~m}$ asl (Table 1) are most visible around Tianzi Mountain (Fig. 4a). Here elevations of $>1000 \mathrm{~m}$ asl (subcatchments ZGC-1, 2 and 4) coincide with the occurrence of Permian limestone overlying resistant ferruginous quartz sandstone (D3h) forming a table mountain with plateau character (Fig. 4a, b). High elevations of $>1200$ m, however, are not limited to Permian limestone and also occur at peaks of more limited spatial extent in Silurian (S2x, S2xS; ZGC-3) or Devonian sandstone (D2yn; ZGC-1) (Fig. 4a, b). Similar peak heights in all sub-catchments (Table 1) are thus indicating that the erosional landscape in the study area may have evolved from a common, preexisting planation surface (P1) (Fig. 2). Mean slopes of all six sub-catchments vary between 20 and $30^{\circ}$ (Table 1 ) while steepest slopes $\left(>40^{\circ}\right.$ ) characterize the valley flanks along much of the stream network, but are most pronounced immediately around the margins of Tianzi Mountain (ZGC-2, 4; Fig. 4c) highlighting its plateau character. Furthermore, topography shows no obvious relationship to geological structure. In fact, Tianzi Mountain plateau coincides with a structural low of two superimposed synclines (Fig. 4b), suggesting that the formation of the planation (P1) and erosional (L1) surfaces significantly postdates major structural movements. The area covered by peak-forest landforms and by the Devonian D2yn formation in the sub-catchments varies between 14 and 68\%, and 11 and 60\%, respectively (Table 1). Sandstone pillar and peak-forest landforms generally occur in the Devonian D2yn quartzitic sandstone (Fig. 4b). However, the data also shows that peak-forests may be absent in areas of dominant quartzitic sandstone (ZGC-6), or can be developed in other lithologies (ZGC-4).

[Fig. 4]

[Table 1]

Valley floor width along the upper Suoxi River is variable and ranges between a few tens of meters in the narrowest canyons up to several hundred meters near ZGC-5 and 6 (Fig. 5). Tributaries have high gradients and show well-developed step-pool sequences (Fig. S3d,e,f). Of the seven knickzones identified in our study area upstream of Wulingyuan, two are stationary and owe their existence to steepening 
due to lithological variations, whereas the remaining five knickzones have been interpreted to be transient (Shi and Shao, 2014). Discontinuous bedrock strath terraces are common and range between $\sim 0.5$ to $4 \mathrm{~m}$ height. They are particularly well-developed just downstream of knickzones and sometimes have preserved evidence for fluvial erosion and sculpturing (Fig. S2a,d,e). Grain size in stream beds is variable, gravelly and poorly-sorted with an overall downstream fining trend towards the Wulingyuan reservoir (Fig. S3b,c,h). Grain shapes vary between subrounded and angular. Fill terraces are rare, and their thickness does not exceed $\sim 5 \mathrm{~m}$ above the river bed. At the foot of the mostly vertical walls of the sandstone towers and pillars lining the valley floors, colluvial cones of variable size have accumulated from mass-wasting processes such as rockfalls of variable size, and spalling and flaking of smaller clasts due to physical weathering (e.g. Fig. S1b,c,f). From the five measured valley cross-sections, the cross-sectional area of these colluvial cones scales with valley width, ranging from $\sim 1 \mathrm{~m}^{2}$ to $>250 \mathrm{~m}^{2}$ (Fig. 5). Grain size of the colluvial cones is highly variable with maximum boulder diameters between 0.5 and $>5 \mathrm{~m}$ and an often clay-rich fine-grained matrix. The majority of the boulders are very angular, as seen from the well preserved bedding planes and joint faces along the boulder sides (Fig. S1b,c).

[Fig. 5]

Most outer surfaces of sandstone peak walls, towers and pillars are vertical to nearvertical (Fig. 3d) with some variations owing to overhangs and arch forms on the order of several 10 s of meters (Fig. $3 d$ ). On a smaller scale $(<10 \mathrm{~m})$, most surfaces are more heterogeneous, likely reflecting preferential physical weathering processes such as spalling or rockfalls along the sub-horizontal to slightly inclined sandstone bedding planes (Fig. S1d) or vertical joints and fractures (Fig. 3d). Around Tianzi Mountain many of the peak walls and towers are located at an elevation between 900-1000 $\mathrm{m}$ asl and are capped by reddish, hematite bearing rocks of the D3h formation at the erosion surface L1 (Yang et al., 2010; Yang et al., 2012). Pillar peaks below this elevation are indicative of the progressing decay of the peakforests, and range in appearance from bare bedrock platforms to dense vegetation cover (e.g., Fig. 3c,d,e). 


\section{$\underline{\text { Cosmogenic Nuclides }}$}

The measured ${ }^{10} \mathrm{Be}$ concentration in all bedrock samples varies considerably and ranges between $\sim 18$ and $1440 \times 10^{3}$ atoms $g^{-1}$ (Table 2, Fig. 6). Generally, lower concentrations $\left(-22-31 \times 10^{3}\right.$ atoms $\left.\mathrm{g}^{-1}\right)$ are observed from the bedrock straths along the narrow channel floors (ZGW-1 to 4 ; Table 2). The ${ }^{10} \mathrm{Be}$ concentrations are variable $\left(\sim 18-79 \times 10^{3}\right.$ atoms $\left.g^{-1}\right)$ for the vertical peak walls (ZGW-5 to 9; Table 2). The peak wall top indicates the highest concentration $\left(\sim 1440 \times 10^{3}\right.$ atoms $\mathrm{g}^{-1}, \mathrm{ZGW}$ 12; Table 2). The model maximum-limiting bedrock erosion rates based on these ${ }^{10} \mathrm{Be}$ concentrations are calculated to be $\sim 83-122 \mathrm{~mm} \mathrm{kyr}^{-1}$ for the bedrock straths (ZGW-1 to 4), 29-140 $\mathrm{mm} \mathrm{kyr}^{-1}$ for the vertical walls (ZGW5-9) and $\sim 3 \mathrm{~mm} \mathrm{kyr}{ }^{-1}$ for the peak summit (ZGW12) (Table 2).

\section{[Table 2]}

The measured ${ }^{10} \mathrm{Be}$ concentrations for river sand samples range from $\sim 44$ to $157 \mathrm{x}$ $10^{3}$ atoms $\mathrm{g}^{-1}$ (Table 3 ). The calculated catchment-wide denudation rates vary between $\sim 26$ to $\sim 96($ mean $=55 \pm 25$ at $1 \sigma) \mathrm{mm} \mathrm{kyr}^{-1}$ (Table 3, Fig. 6). Due its location further downstream, the catchment-wide denudation rate for ZGC-5 (48 $\left.\pm 11 \mathrm{~mm} \mathrm{kyr}{ }^{-1}\right)$ integrates over a catchment area that also includes ZGC-1 to 4. The coarser (pebblesize) grain size aliquot (ZGC-1(III)) indicates $\sim 20 \%$ lower ${ }^{10} \mathrm{Be}$ concentration than the sand-size aliquot (ZGC-1(IV)) (Table 3). This results in a $\sim 20 \%$ higher catchmentwide denudation rate for the former than the latter, even though the calculated rates are essentially consistent within $1 \sigma$ error.

The rates indicate no clear relationship with catchment areas (Fig. 6b), whereas the rates generally exhibit positive relationships with mean catchment slope and relative area covered by Permian limestone (Fig. 6c,d), and show an inverse relationship existing between the denudation rates and the relative area covered by Silurian sandstone (Fig. 6e). In all cases, however, the sample ZGC-6 appears to deviate from these general trends. No clear relationship exists between the denudation rate and the relative area of well-developed peak-forest landforms (Fig. 6f).

[Table 3]

This article is protected by copyright. All rights reserved. 


\section{Discussion}

The significance of ${ }^{10} \mathrm{Be}$-derived denudation rates

The model erosion rates determined in this study from bedrock and sediment samples provide the first quantitative measure for the magnitude of the erosional processes in the sandstone pillar and peak-forest landscapes at Zhangjiajie. The low denudation rate from the top of the sandstone peak wall top (ZGW-12, $\sim 3 \mathrm{~mm} \mathrm{kyr}{ }^{-1}$; Fig. 6a, Table 2) is interpreted as the most probable maximum limiting subaerial erosion rate, and refers to a measure of the vertical lowering rate of the Devonian sandstone surfaces in the area. This slow denudation is consistent with the fact that the summit of the peak-forests are now well isolated from active mass-wasting and fluvial incision observed at lower elevations, and which are responsible for the evolution of the pillar and peak-forest landscapes. The sample is situated $\sim 7 \mathrm{~m}$ below the L1 erosional surface $(\sim 950 \mathrm{~m}$ asl). Due to the topographically and stratigraphically elevated setting on the peak wall top, this quartzitic sandstone sample may reflect the combined concentration from an inheritance inventory at a lower production rate during the period in which the ferruginous sandstone D3h capping weathered, and a sub-aerial exposure history during the following peakforest evolution.

In contrast, the consistently high denudation rates ( 83-122 $\mathrm{mm} \mathrm{kyr}^{-1}$; Table 2; mean of $110 \pm 17 \mathrm{~mm} \mathrm{kyr}^{-1}$ at $1 \sigma$ ) obtained from the bedrock straths along the channel floor reflect a relatively uniform base-level and valley lowering rate. These rates are somewhat lower than the previously published rates for fluvial incision of 170 to 224 $\mathrm{mm} \mathrm{kyr}^{-1}$ in the upper Suoxi catchment (Shi and Shao, 2014).

The lower range and far larger variability in denudation rates observed from the vertical sandstone peak walls ( 29-140 $\mathrm{mm} \mathrm{kyr}^{-1}$ ) reflects the irregular temporal and spatially heterogeneous nature of the erosional processes dominated by block spalling and rock falls acting on the vertical surfaces. Our field observations identified frequent spalling scars, indicating that such processes are ongoing and of importance for the net retreat of these surfaces. Rock falls cause the irregular 
cantilevered morphology on vertical wall outcrops (Fig. S1d), producing the coarser, angular rock debris stored in the colluvial footslopes along the valley floors (Fig. S1b,c,f). In addition, given the dense vegetation cover root cracking could also play a role on net cliff retreat (Fig. 3d,e, Fig. S1e). Considering the diversity of active cliff retreat processes we therefore average erosion rates from all five vertical wall samples resulting in $67 \pm 47 \mathrm{~mm} \mathrm{kyr}^{-1}$. As horizontal wall retreat is a stochastic process that presumably involves varying spalling scales from decimetres to meters, multiple data points from randomly sampled locations across various wall geometries would be required to provide a statistically more reliable mean. In the context of our dataset, however, the erosion rate from ZGW-8 at $140 \mathrm{~mm} \mathrm{kyr}{ }^{-1}$ is considerably higher than the rates for the remaining four samples and likely represents a relatively recent spalling event. Therefore, we argue that the average rate without ZGW-8 $\left(48 \pm 26 \mathrm{~mm} \mathrm{kyr}^{-1}\right)$ should provide a more realistic estimate of long-term wall retreat.

This average cliff wall retreat rate falls within the range of most published values ( $7-$ $66 \mathrm{~mm} \mathrm{kyr} \mathrm{r}^{-1}$ ) for the lowering and retreat of sandstone surfaces based on experimental studies (Turkington and Paradise, 2005). Comparable rates are also reported, based on cosmogenic nuclide measurements, for the escarpment retreat in the temperate, humid climate settings from the Drakensberg, SE Africa $\left({ }^{36} \mathrm{Cl}, 50-95\right.$ mm kyr ${ }^{-1}$ ) and Sri Lanka $\left({ }^{10} \mathrm{Be}, 20-70 \mathrm{~mm} \mathrm{kyr}^{-1}\right)$ (Fleming et al., 1999; Vanacker et al., 2007).

The calculated catchment-wide denudation rates $\left(\sim 26-96 \mathrm{~mm} \mathrm{kyr}^{-1}\right.$; Table 3; mean of $55 \pm 25$ at $1 \sigma$ ) are within error of the mean vertical wall retreat rates based on bedrock samples of $48 \pm 26 \mathrm{~mm} \mathrm{kyr}^{-1}\left(\sim 29-86 \mathrm{~mm} \mathrm{kyr}^{-1}\right.$ when rejecting ZGW-8, Table 2 ), but both sets of denudation rates are distinctly lower by a factor of 2 from the mean valley lowering rate of $110 \pm 17 \mathrm{~mm} \mathrm{kyr}^{-1}$ and significantly higher than the peak summit denudation rate $\left(\sim 3 \mathrm{~mm} \mathrm{kyr}^{-1}\right.$; Table 2$)$. The catchment-wide denudation rates increase with mean slopes, and generally with area of peak-forest, except for sub-catchment ZGC-2 and 6, which somewhat deviate from the trend (Fig. 6). Only $18 \%$ of ZGC- 6 are characterized by peak-forest landforms, even though $51 \%$ of its area are occupied by quartzitic sandstone (Table 1). However, the ZGC-6 catchment is structurally characterized by a prominent NNE trending anticline (Fig. 4b) leading to relatively higher slope values $\left(\sim 30^{\circ}\right)$ than in the other sub-catchments $\left(\sim 21-25^{\circ}\right.$; 
Table 1) and steeper inclinations of the sandstone bedding planes (Fig. 2e). This would have effectively limited the formation of the well-developed sandstone peakforest (i.e. high spatial density of high sandstone pillars) due to reduced mechanical stability. Catchment ZGC-2 indicates the highest denudation rate with moderate areas of sandstone peak-forest cover but highest areas of overlying Permian limestone (Fig. 6d,e). This sub-catchment occupies a position along the plateau margin around Tianzi Mountain. Considering that headward extension of the fluvial system is active along joints via the upstream propagation of successive knickzones (Shi and Shao, 2014), our results imply that denudation rates are commonly high along the plateau margin due to rapid fluvial incision.

\section{A model for sandstone peak-forest evolution}

A sequential model for the geomorphic evolution of these sandstone landscapes has been suggested based on the relationship between topography and sandstone morphology (Fig. 2): (i) intermittent but ongoing late Cenozoic uplift of $\sim 0.2 \mathrm{~mm} \mathrm{a}^{-1}$ (Yang et al., 2011b), (ii) preferential fluvial dissection of the quartzitic sandstone along fault lines and joints (Yang et al., 2012), and (iii) successive fluvial headward incision of $\sim 0.224 \mathrm{~mm} \mathrm{a}^{-1}$ by knickpoint propagation (Shi and Shao, 2014). The observed diverse nature of the wall retreat processes and the consistency between the average vertical wall retreat rates and average catchment-wide erosion rates, however, highlight the importance of cliff retreat processes in the overall erosion of the sandstone peak-forest landscape in Zhangjiajie. Although the valley-floor lowering rate is clearly 2 times larger than the cliff retreat rates and overall basin wide erosion rates, the latter two processes, acting on vastly larger surface areas, would be much more important in net sediment production than the former which is confined to partially exposed bedrock outcrops along the stream channel floors. Assuming densities of $2.7 \mathrm{~g} \mathrm{~cm}^{-3}$ for the eroded rock mass, sub-catchment specific unit erosion rates are calculated to be from $\sim 71$ to $260 \mathrm{t} \mathrm{km}^{-2} \mathrm{yr}^{-1}$ (Table 4) and fall well into the reported range for regional sediment yields of 86 (>2007) to $469 \mathrm{t} \mathrm{km}^{-2} \mathrm{yr}^{-1}$ (19541986) (Zheng, 2014). Overall, our results thus confirm the spatially (and also temporally) varying nature of denudation rates at the summit, escarpment and footslope during tableland formation and degradation (Boroda et al., 2014), and suggest that vertical wall retreat is the dominant process of sediment production in 
the catchments characterized by peak-forest. Therefore, our findings highlight the importance of wall retreat processes, in addition to fluvial processes, for the longerterm erosional history of the sandstone peak-forest.

We hence propose the following landscape evolution model, incorporating both valley deepening and widening, for the transformation from peak walls and table mountains into the multitude of sandstone towers and pillars in Zhangjiajie (Fig. 7):

[Fig. 7]

(i) Erosional processes would have followed the relief generated by uplift of a low-relief planation surface P1. Denudation rates for this stage are difficult to estimate, particularly in limestone lithologies, e.g. at Tianzi Mountain, where karstification would have been the dominant denudation process. Nevertheless, the denudation rate of $\sim 3 \mathrm{~mm} \mathrm{kyr}^{-1}$, determined in this study for the summit of the peak walls (ZGW-12; Table 2), probably best represents the slow downwearing processes associated with the highly resistant D3h formation and the development of a table mountain morphology.

(ii) During the early stage of plateau dissection, denudation rates must be relatively high (e.g., $\sim 96 \mathrm{~mm} \mathrm{kyr}^{-1}$, ZGC-2; Table 3) aided by high slopes around the plateau margin and the headward propagation of successive knickzones and valley lowering by fluvial incision ( 83-122 mm kyr ${ }^{-1}, \mathrm{ZGW}-1$ to 4 ; Table 2) along joints and fractures as zones of reduced rock strength (Shi and Shao, 2014). This also explains the positive relationship between subcatchment area occupied by overlying Permian limestone and denudation rates (Figs. $6 \mathrm{~d}$ and 7 ). Preferential chemical pre-weathering along the densely developed joint and fracture network could have initially enhanced fluvial incision and fast valley lowering (Busche et al., 2005), though detailed mapping of joints did not provide clear evidence for chemical alteration in the study area (Yang et al., 2012).

(iii) Vertical valley lowering by fluvial incision is followed by the increasing contribution of vertical wall retreat via physical weathering processes (e.g. spalling, rock falls) with relatively lower, but variable erosion rates ( $29-140$ $\mathrm{mm} \mathrm{kyr}{ }^{-1}, \mathrm{ZGW}-5$ to 9 ; Table 2). Consequently sub-catchments with well- 
developed peak-forest landscapes (e.g. ZGC-4 with highest fraction of peakforest landscape) have intermediate catchment-wide denudation rates ( 32 $72 \mathrm{~mm} \mathrm{kyr}{ }^{-1}$ for ZGC-1, -4 and -5 ; Table 3), which act on large surface areas and thus dominate bedload sediment.

(iv) Finally, denudation rates will further decrease (e.g., $\sim 26 \mathrm{~mm} \mathrm{kyr}{ }^{-1}$ for ZGC-3; -Table 3) as sandstone peak-forest landscapes are consumed by progressive erosion leading to a reduction in vertical wall area, mean slope (Fig. 6c) and the successive exposure of the underlying Silurian sandstones (Fig. 6e) in the later stages of peak-forest evolution.

\section{Estimating the age of the peak-forest landscape at Zhangiiajie}

In this section, we will estimate the timing of the onset of sandstone peak-forest landscapes at Zhangjiajie by relating our (i) average fluvial downcutting rate to the relief (i.e. maximum denudation depth) created between the erosional surface L1 and the modern base-level of each sub-catchment, and (ii) denudation rate estimates to the total eroded volume since the peak-forest initiation. According to the existing model of peak-forest evolution (Yang et al., 2012), the relief between the regional erosional surface L1 and the lowermost channel floor in each sub-catchment should reflect base-level lowering by the ongoing dissection of the D2yn sandstone. It varies between $\sim 450$ and $550 \mathrm{~m}$ (Table 4). Also, the total eroded volume should equal the removed volume below $\sim 950 \mathrm{~m}$ asl, the regional erosional surface L1 on top of the ferruginous sandstone (D3h) preceding the dissection of the D2yn sandstone (Fig. 2). We estimated the total removed volume for each sub-catchment using four different elevation models (Table 4). The four models yielded very similar values for a given catchment and we used average volumes from all DEMs below $950 \pm 25 \mathrm{~m}$ asl for further calculation (Table 4). Depending on catchment size and morphology, the eroded volume ranges from $\sim 0.5$ to $9.4 \mathrm{~km}^{3}$ for the sub-catchments, with a total of $\sim 10.2 \pm 1.3 \mathrm{~km}^{3}$ (i.e. ZGC-5 and 6) eroded from all sampled sub-catchments in the upper Suoxi catchment. GIS-derived average denudation thicknesses vary from $\sim 132$ to $>200 \mathrm{~m}$.

In addition to complete evacuation from the sub-catchments, material eroded from table mountains, peak walls, pillars and valley floors may have been stored in 
colluvial cones occupying the transition between the vertical walls and valley floors, thus potentially complicating the use of denudation thicknesses for the calculation of erosional timescales. Assuming colluvial sediment storage with our measured maximum cross-sectional areas of $250 \mathrm{~m}^{2}$ around all $>3000$ mapped pillars ( $\mathrm{Hu}$, 2011; Yang et al., 2011a) would only account for $\sim 1.0 \%$ of the total eroded volume and is thus insignificant for the longer-term erosional history of the Zhangjiajie landscape. Average peak heights were determined from the analysis of highresolution remote sensing imagery and range in the literature between $\sim 95-150 \mathrm{~m}$ (Hu, 2011; Yang et al., 2011a; Yang et al., 2012)(Fig. 2). With the measured range of vertical wall retreat rate $\left(\sim 29-140 \mathrm{~mm} \mathrm{kyr}^{-1}\right)$ and averaged published peak heights the accumulation of cross-sectional areas of most measured colluvial cones $\left(1-250 \mathrm{~m}^{2}\right)$ in the study area would correspond to sediment residence times of $\sim 50-90,000 \mathrm{yrs}$. In combination, this would imply that sediment stored in these cones does not remain in the catchments on longer timescales, and is effectively removed on millennial timescales, e.g. via chemical weathering, or through lateral erosion and hillslope failure by landsliding transferring the material to the fluvial system (Fig. S1f).

Another important consideration is that the denudation rates based on cosmogenic nuclide measurements are subject to averaging timescales that are required for an exposed bedrock surface to achieve steady-state ${ }^{10} \mathrm{Be}$ concentrations representing equilibrium between erosion (plus decay) and production (Lal, 1991). For a given rate, saturation occurs after removal of $\sim 3$ spallation attenuation lengths $(\sim 3 \times 60 \mathrm{~cm}$ for bedrock with density at $\left.2.7 \mathrm{~g} \mathrm{~cm}^{-3}\right)$. In this study the equilibrium averaging time ranged from $\sim 15$ to $75 \mathrm{kyr}$ (not including ZGW-12, the peak summit sample) (Table 2, 3). These timescales should effectively integrate millennial scale changes in monsoonal intensity and associated variability in vegetation cover, flood frequency or magnitude and thus fluvial erosional processes (Wang et al., 2008; Penny, 2012). The glacial-interglacial cycles on timescales of $10^{5}$ years may have also induced variations in regional temperature and monsoon dynamics in China (Kukla and An, 1989; Liu et al., 2003; Sun et al., 2003; An et al., 2011), and in turn denudation processes in our study area, e.g. via changes in precipitation and discharge, vegetation cover or frost related weathering processes. In a scenario of increased physical weathering with lowered temperatures during glacial periods, our denudation 
rates should thus be taken as minimum and the resulting age estimate for the peakforest formation, below, as maximum.

The onset of sandstone peak-forest formation was estimated using two scenarios based on the mean valley lowering rate and basin average denudation rates, respectively. In the first scenario, the average valley lowering rate measured in the narrow valley floor (i.e. $110 \pm 17 \mathrm{~mm} \mathrm{kyr}^{-1}$ ) was applied to the relief between the erosional surface L1 (taken as $950 \pm 25 \mathrm{~m}$ for all basins) and base-level elevation. This resulted in the length of time required for the onset of successive dissection of the D2yn sandstone in each sub-catchment of between $\sim 4.1$ and $5 \mathrm{Ma}$, thus also providing an upper limit for the onset of peak-forest evolution in Zhangjiajie (Table 4). Pliocene ages of $\sim 2.7$ and $3.4 \mathrm{Ma}$ would also result if previously published regional fluvial downcutting rates of $\sim 180$ to $224 \mathrm{~mm} \mathrm{kyr}^{-1}$ (Yang et al., 2012; Shi and Shao, 2014) are applied to the total generated vertical relief in the region ( $\sim 608 \mathrm{~m})$ between the erosional surface L1 and the local base-level at Wulingyuan Town. However, if we assign our measured average valley lowering rate to the average denudation thickness (Table 4) in each sub-catchment, the estimated timescales would result in 1.2-2.0 Ma. Although these ages are in line with the previously reported early-mid Pleistocene ages (Yang et al., 2012; Shi and Shao, 2014), they are not compatible with the notion of a time transgressive decrease in denudation rates due to the increasing importance of wall retreat as suggested by our landscape evolution model (Fig. 7). Therefore, these timescales would thus substantially underestimate the onset of peak-forest formation and should be considered minimum limiting ages.

For our second scenario, onset ages were estimated based on sub-catchment specific denudation rates and the average denudation thickness (Table 4), resulting in generally higher ages with four of the catchments showing initiation from 3.0 to 4.7 $\mathrm{Ma}$ and two others at 7.8 Ma (ZGC-3) and 1.3 Ma (ZGC-2) (Table 4). The catchmentspecific denudation rates used in this scenario integrate temporal variation in the rates for the last $\sim 75 \mathrm{ka}$ (Table 3 ) and are considered the minimum-limiting rates in the overall erosional history. Consequently, the age estimates for this second scenario can also be regarded as the maximum estimates for the onset of peakforest formation in each sub-catchment. Individual sub-catchments vary in terms of their lithology as a function of both time (Fig. 7) and the specific geological situation 
(i.e. bedding and structure; Fig. 4b), and as lithology exerts a strong control on erosion and denudation rates (e.g. Morel et al., 2003), the variation in these age estimates likely reflects the diversity in lithology and thus historical erosional pathways among the sub-catchments.

Given the excellent agreement in timescales for the two scenarios our model of spatially and temporally varying relative contributions of fluvial erosion vs vertical wall retreat in combination with sub-catchment specific denudation rates suggests the early Pliocene onset of erosional processes for the dissection of the erosional surface L1 around Tianzi Mountain. While it highlights the role of rapid fluvial downcutting in counteracting regional uplift by lowering local base-level as a major driver for landscape evolution, it also shows that processes of vertical wall retreat are required to account for the total erosional volume since the Pliocene.

In the absence of regional uplift records in Southern Central China, the notion of a strong pulse of exhumation, lateral extension and uplift along the eastern Tibetan plateau in the late Miocene (Harrison et al., 1992; Hodges and Coleman, 1995; Clark et al., 2005; Wang et al., 2012; Lang et al., 2016) would be in agreement with an early initial uplift in the Zhangjiajie area leading to the slow dissection of the planation surface P1 and the formation of extensive karst landscapes. Continued regional uplift would have been followed by the headward expansion of the fluvial network, intensified monsoonal precipitation and erosion in South Central China, and the onset of peak-forest formation at Zhanjiajie as early as in the Pliocene (i.e. 3-5 Ma) determined in this study - a scenario also supported by increased terrestrial erosion as seen in the few available sedimentary records from the South China Sea (Van Hoang et al., 2010).

\section{$\underline{\text { Implications for sandstone geomorphology and peak-forest formation }}$}

Our results also have some implications for the formation of some of the globally most spectacular erosional sandstone landscapes that are commonly characterized by groups of closely-spaced, tall bedrock towers, pillars or pinnacles. While a consistent terminology for these landscapes is still absent and has remained rather descriptive (e.g. 'peak-forest' in our study area, 'rock cities' or 'ruiniform relief' 
elsewhere; Migoń et al., 2017) there is general consensus that a wide range of processes contribute to their formation, thus also introducing a remarkable degree of geomorphic variety among the globally (Young et al., 2009; Migoń et al., 2017) or regionally (Yang et al., 2012) documented examples.

Our results are (i) generally consistent with the idea of an interplay between the weathering driven production of material, and its subsequent evacuation as a key process for the formation and maintenance of peak-forest landscapes (Migoń et al., 2017). In this context, fluvial erosion and downcutting via knickzone propagation is widespread and still ongoing in Zhangjiajie (Shi and Shao, 2014). This is also reflected by highest erosion rates along the valley floors, but is contrary to the generally minor role assigned to fluvial erosion in the longer-term evolution of many peak-forest landscapes elsewhere (Migoń et al., 2017). In comparison with peakforest landscapes located in tectonically rather stable settings such as central Europe (Adamovič et al., 2006; Cílek, 2010), northern Australia (Young, 2009; Young et al., 2009) or the central Sahara (Busche and Erbe, 1987), the ongoing tectonic activity in relation to the Himalayan orogeny and the concomitant onset of a monsoonal precipitation regime could provide one possible explanation for the significant contribution of fluvial processes in counterbalancing regional uplift and creating the relief required for the formation of the particularly high, densely-spaced and welldeveloped landforms at Zhangjiajie (Yang et al., 2012). In addition, (ii) the ongoing headwards expansion of fluvial downcutting by knickzone propagation highlights that the evolutionary stages which commonly describe the time-transgressive progression of peak-forest development and decay in the few existing conceptual models (Cílek, 2010; Yang et al., 2012) need to be placed both in temporal and spatial contexts. More specifically, the lateral and horizontal expansion of the peak-forest should lead to the co-existence of "landscape stages" of different age, providing a potentially valuable and underexplored conceptual approach towards the interpretation and testing of geomorphic dynamics and overall landscape age. The participation and interplay of various processes has long been recognized as characteristic in most sandstone landscapes (Migoń et al., 2017), but our results for the first time (iii) allow assessing their relative temporal and spatial significance. In this context, it has proved particularly crucial to quantify the effectiveness of wall retreat which is characterized by lower absolute erosion rates compared to fluvial downcutting but 
accounts for vastly larger areas. It should therefore be a key parameter for the reconstruction of landscape evolution in Zhangjiajie and elsewhere. Finally, the determination of process rates will prove crucial in testing of existing evolutionary models, and is thus required towards a more process based understanding of the geomorphic differences and similarities that are so typical for the wide range of existing peak-forest landscapes around the globe.

\section{Conclusions}

Our study has shown that cosmogenic nuclides in combination with GIS analysis are powerful tools to establish rates of erosion in sandstone landscapes - even in very complex landscapes such as the sandstone peak-forest at Zhangjiajie. Our results confirm that the formation of a sandstone peak-forest undergoes stages of varying erosion rates and relative contributions of erosive processes, i.e. initial fast valley lowering by fluvial incision followed by moderate vertical wall retreat, and formation and decline of sandstone towers and peaks. Based on measured denudation rates and erosional volumes derived from four different elevation models, the maximum Pliocene (or as early as late Miocene) ages for the onset of sandstone peak-forest at Zhangjiajie are suggested.

The evolutionary denudation model presented in this study improved our understanding in the erosion processes and timescales of the sandstone peak-forest formation, where we: (i) account for the important role of vertical wall retreat in the overall erosional history of the landscape, (ii) reconcile the few previously published uplift and fluvial downcutting rates, and (iii) agree with the major tectonic and erosional events recorded along the eastern Himalaya and the South China Sea. Future work may help to directly constrain local uplift rates, e.g. with thermochronometric approaches, and will benefit from the incorporation of new generations of spatially highly resolved DEMs to improve estimates of erosional volumes and vertical wall area. In Zhangjiajie, our refined model of sandstone peakforest formation thus awaits further detailed testing specifically targeting subcatchments at different stages of their development. Finally, our study has shown the large potential for application in other sandstone landscapes required to advance our understanding of the complex relationship between the multiple processes, their rates 
and controlling variables contributing to the formation of sandstone landscape diversity around the globe.

\section{Acknowledgements}

The authors would like to thank Zhangjiajie Global Geopark for logistical support. This study was financially supported by the Joint Research Center for Zhangjiajie Geomorphology based in the Institute of Geographical Sciences and Natural Resources Research of the Chinese Academy of Sciences, a project funded by Zhangjiajie Global Geopark, National Natural Science Foundation of China project (No. 41202134), and a Young Scientist Fellowship award by the Chinese Academy of Sciences to Dr. Jan-Hendrik May. The clear and constructive comments of two anonymous reviewers are gratefully acknowledged.

\section{References}

Adamovič J, Mikuláš R, Cílek VG. 2006. Sandstone districts of the Bohemian Paradise: Emergence of a romantic landscape. Geolines 21: 1-100

Amato A, Aucelli $P$, Cinque A. 2003. The long-term denudation rate in the Southern Apennines Chain (Italy): a GIS-aided estimation of the rock volumes eroded since middle Pleistocene time. Quaternary International 101: 3-11

An Z, Clemens SC, Shen J, Qiang X, Jin Z, Sun Y, Prell WL, Luo J, Wang S, Xu H. 2011. Glacial-interglacial Indian summer monsoon dynamics. Science 333: 719-723

Balco G, Stone JO, Lifton NA, Dunai TJ. 2008. A complete and easily accessible means of calculating surface exposure ages or erosion rates from 10Be and 26Al measurements. Quaternary Geochronology 3: 174-195

Boroda R, Matmon A, Amit R, Haviv I, Arnold M, Aumaître G, Bourlès DL, Keddadouche K, Eyal Y, Enzel Y. 2014. Evolution and degradation of flat-top mesas in the hyper-arid Negev, Israel revealed from 10Be cosmogenic nuclides. Earth Surface Processes and Landforms 39: 1611-1621. DOI: 10.1002/esp.3551

Braucher R, Merchel S, Borgomano J, Bourlès D. 2011. Production of cosmogenic radionuclides at great depth: a multi element approach. Earth and Planetary Science Letters 309: 1-9

Brierley G, Huang HQ, Chen A, Aiken S, Crozier M, Eder W, Goudie A, Ma Y, May JH, Migon P, Nanson G, Qi D, Viles H, Wood C, Wray R, Yang G, Yang X, Yu G-a. 
2011. Naming conventions in geomorphology: contributions and controversies in the sandstone landscape of Zhangjiajie Geopark, China. Earth Surface Processes and Landforms 36: 1981-1984. DOI: 10.1002/esp.2216

Busche D, Erbe W. 1987. Silicate karst landforms of the southern Sahara (northeastern Niger and southern Libya). Zeitschrift fur Geomorphologie Supplement 64: $55-72$

Busche D, Kempf J, Stengel I. 2005. Landschaftsformen der Erde. Wissenschaftliche Buchgesellschaft: Darmstadt

Chen C, Xie B. 1994. Study for Establish a New Type of Pillar Peak Sandstone Geomorphy in Zhang Jia Jie Hunan China. Acta Sci. Nat. Univ. Norm. Hunan 17: 8487

Chen G. 1993. Geotectonic conditions of formation of the Wulingyuan peak-forest landform, China. Geotectonica et Metallogenia 17: 103-112

Child D, Elliott G, Mifsud C, Smith A, Fink D. 2000. Sample processing for earth science studies at ANTARES. Nuclear Instruments and Methods in Physics Research Section B: Beam Interactions with Materials and Atoms 172: 856-860

Chmeleff J, von Blanckenburg F, Kossert K, Jakob D. 2010. Determination of the 10 Be half-life by multicollector ICP-MS and liquid scintillation counting. Nuclear Instruments and Methods in Physics Research Section B: Beam Interactions with Materials and Atoms 268: 192-199

Cílek V. 2010. Saxon-Bohemian Switzerland: sandstone rock cities and fascination in a romantic landscape. In Geomorphological Landscapes of the World. Springer; 201209.

Clark MK, House M, Royden L, Whipple K, Burchfiel B, Zhang X, Tang W. 2005. Late Cenozoic uplift of southeastern Tibet. Geology 33: 525-528

Clift PD, Plumb RA. 2008. The Asian monsoon: causes, history and effects. Cambridge University Press Cambridge

Codilean AT. 2006. Calculation of the cosmogenic nuclide production topographic shielding scaling factor for large areas using DEMs. Earth Surface Processes and Landforms 31: 785-794

Compo GP, Whitaker JS, Sardeshmukh PD, Matsui N, Allan RJ, Yin X, Gleason BE, Vose RS, Rutledge G, Bessemoulin P, Brönnimann S, Brunet M, Crouthamel RI, Grant AN, Groisman PY, Jones PD, Kruk MC, Kruger AC, Marshall GJ, Maugeri M, Mok HY, Nordli $\varnothing$, Ross TF, Trigo RM, Wang XL, Woodruff SD, Worley SJ. 2011. The Twentieth Century Reanalysis Project. Quarterly Journal of the Royal Meteorological Society 137: 1-28. DOI: 10.1002/qj.776 
Cui Z, Li D, Feng J, Liu G, Li H. 2002. The covered karst, weathering crust and karst (double-level) planation surface. Science in China (Series D) 45: 366-379

Dunai TJ. 2010. Cosmogenic Nuclides: Principles, Concepts and Applications in the Earth Surface Sciences. Cambridge University Press.

ESRI. 2015. ArcGIS 10.4 Help.

Farr TG, Rosen PA, Caro E, Crippen R, Duren R, Hensley S, Kobrick M, Paller M, Rodriguez E, Roth L, Seal D, Shaffer S, Shimada J, Umland J, Werner M, Oskin M, Burbank D, Alsdorf D. 2007. The Shuttle Radar Topography Mission. Rev. Geophys. 45: RG2004

Fink D, Smith A. 2007. An inter-comparison of 10 Be and 26 Al AMS reference standards and the 10 Be half-life. Nuclear Instruments and Methods in Physics Research Section B: Beam Interactions with Materials and Atoms 259: 600-609

Fleming A, Summerfield M, Stone JO, Fifield LK, Cresswell R. 1999. Denudation rates for the southern Drakensberg escarpment, SE Africa, derived from in-situproduced cosmogenic 36C1: initial results. Journal of the Geological Society 156: 209-212

Granger DE, Schaller M. 2014. Cosmogenic Nuclides and Erosion at the Watershed Scale. Elements 10: 369-374. DOI: 10.2113/gselements.10.5.369

Harrison TM, Copeland P, Kidd P, Yin A. 1992. Raising Tibet. Science 255: 16631670

Hodges K, Coleman M. 1995. Evidence for Tibetan plateau uplift below 14 Myr ago from a new minimum age for east-west extension. Nature: International weekly journal of science 374 : 49-52

Hong R. 2011. Avatar in Zhangjiajie. International Talent 12: 034

Hu HP. 2011. Remote sensing evidence of the three thousand sandstone pillars in Zhangjiajie (in Chinese). Land Resour. Her. 8 (11) 8: 50-52

Huang L-y, Zhu C, Kong Q-y. 2006. The Contribution of Lithological Component to Sandstone Forest Landform Genesis in Zhangjiajie, Hunan Province. Journal of Anhui Normal University ( Natural Science) 29: 484-489

Jarvis A, Reuter HI, Nelson A, Guevara E. 2008. Hole-filled seamless SRTM data V4. International Centre for Tropical Agriculture (CIAT).

Jenson SK, Domingue JO. 1988. Extracting topographic structure from digital elevation data for geographic information system analysis. Photogrammetric Engineering and Remote Sensing 54: 1593-1600 
Kohl CP, Nishiizumi K. 1992. Chemical Isolation of Quartz for Measurement of in-situ produced cosmogenic nuclides. Geochimica et Cosmochimica Acta 56: 3583-3587

Korschinek G, Bergmaier A, Faestermann T, Gerstmann U, Knie K, Rugel G, Wallner A, Dillmann I, Dollinger G, Von Gostomski CL. 2010. A new value for the half-life of 10 Be by heavy-ion elastic recoil detection and liquid scintillation counting. Nuclear Instruments and Methods in Physics Research Section B: Beam Interactions with Materials and Atoms 268: 187-191

Kukla G, An Z. 1989. Loess stratigraphy in central China. Palaeogeography, Palaeoclimatology, Palaeoecology 72: 203-225

Lal D. 1991. Cosmic ray labeling of erosion surfaces: In situ nuclide production rates and erosion models. Earth and Planetary Science Letters 104: 429-439

Lang KA, Huntington KW, Burmester R, Housen B. 2016. Rapid exhumation of the eastern Himalayan syntaxis since the late Miocene. Geological Society of America Bulletin 128: 1403-1422

Li J, Xie S, Kuang M. 2001. Geomorphic evolution of the Yangtze Gorges and the time of their formation. Geomorphology 41: 125-135. DOI: 10.1016/S0169$555 \times(01) 00110-6$

Liu Z, Trentesaux A, Clemens SC, Colin C, Wang P, Huang B, Boulay S. 2003. Clay mineral assemblages in the northern South China Sea: implications for East Asian monsoon evolution over the past 2 million years. Marine Geology 201: 133-146

Mifsud C, Fujioka T, Fink D. 2013. Extraction and purification of quartz in rock using hot phosphoric acid for in situ cosmogenic exposure dating. Nuclear Instruments and Methods in Physics Research Section B: Beam Interactions with Materials and Atoms 294: 203-207

Migoń P, Duszyński F, Goudie A. 2017. Rock cities and ruiniform relief: Formsprocesses-terminology. Earth-Science Reviews 171: 78-104

Morel P, von Blanckenburg F, Schaller M, Kubik PW, Hinderer M. 2003. Lithology, landscape dissection and glaciation controls on catchment erosion as determined by cosmogenic nuclides in river sediment (the Wutach Gorge, Black Forest). Terra Nova 15: 398-404. DOI: 10.1046/j.1365-3121.2003.00519.x

Mudd SM, Harel M-A, Hurst MD, Grieve SW, Marrero SM. 2016. The CAIRN method: automated, reproducible calculation of catchment-averaged denudation rates from cosmogenic nuclide concentrations. Earth Surface Dynamics 4: 655-674

NASA LP DAAC. 2016. Advanced Spaceborne Thermal Emission and Reflection Radiometer (ASTER) Global Digital Elevation Model Version 2 (GDEM V2). NASA EOSDIS Land Processes DAAC, USGS Earth Resources Observation and Science (EROS) Center: Sioux Falls, South Dakota. 
Ni Z-Y, Yang G-F, Zhang X-J, Tian M-Z, Ping Y-M, Yang Z. 2011. Characteristics of Weathering Crust and Formation Environment of Planation Surface in Zhangjiajie. Geoscience 25: 789-795

Nishiizumi K, Imamura M, Caffee MW, Southon JR, Finkel RC, McAninch J. 2007. Absolute calibration of 10 Be AMS standards. Nuclear Instruments and Methods in Physics Research Section B: Beam Interactions with Materials and Atoms 258: 403413

Pang X-X, Feng J-M, Li X-H, Sang G-S. 2013. Research of Land-use Change in Wulingyuan during the Last 40 Years. Research of Soil and Water Conservation 20: 73-79

Peel MC, Finlayson BL, McMahon TA. 2007. Updated world map of the KöppenGeiger climate classification. Hydrology and earth system sciences discussions 4: 439-473

Penny D. 2012. China and Southeast Asia. Quaternary Environmental Change in the Tropics: 207-235

Ping Y, Yang G, Zhang X, Tian M, Chen A, Ge Z, Ni Z, Yang Z. 2011. Timing of Zhangjiajie Sandstone Landforms: Evidence from Fluvial Terraces and Karst Caves. Geological Review 57: 118-124

Qi CJ, Xiao YT, Cao TR. 1989. Investigation report on forest vegetation in Zhangjiajie-Suoxiyu Natural Reserve Region (Abstract). Hunan Forestry Science and Technology: 5-8

Shi C, Qi D. 2013. Geometric characteristics of valley and basin of Suoshui River in Zhangjiajie of Hunan Province and their implications in landform evolution. Journal of Palaeogeography 15: 865-874

Shi C, Shao W. 2014. Knickpoints within the Suoshui watershed and the implication for the age of sandstone pillars in Zhangjiajie, China. Geomorphology 221: 261-273. DOI: 10.1016/j.geomorph.2014.06.018

Stone JO. 2000. Air pressure and cosmogenic isotope production. Journal of Geophysical Research: Solid Earth 105: 23753-23759

Sun X, Luo Y, Huang F, Tian J, Wang P. 2003. Deep-sea pollen from the South China Sea: Pleistocene indicators of East Asian monsoon. Marine Geology 201: 97118

Tadono T, Ishida H, Oda F, Naito S, Minakawa K, Iwamoto H. 2014. Precise global DEM generation by ALOS PRISM. ISPRS Annals of the Photogrammetry, Remote Sensing and Spatial Information Sciences 2: 71 
Turkington AV, Paradise TR. 2005. Sandstone weathering: A century of research and innovation. Geomorphology 67: 229-253. DOI: 10.1016/j.geomorph.2004.09.028

Van Hoang L, Clift PD, Schwab AM, Huuse M, Nguyen DA, Zhen S. 2010. Largescale erosional response of SE Asia to monsoon evolution reconstructed from sedimentary records of the Song Hong-Yinggehai and Qiongdongnan basins, South China Sea. Geological Society, London, Special Publications 342: 219-244

Vanacker V, von Blanckenburg F, Hewawasam T, Kubik PW. 2007. Constraining landscape development of the Sri Lankan escarpment with cosmogenic nuclides in river sediment. Earth and Planetary Science Letters 253: 402-414. DOI: 10.1016/j.epsl.2006.11.003

von Blanckenburg F, Willenbring JK. 2014. Cosmogenic nuclides: Dates and rates of Earth-surface change. Elements 10: 341-346

Wan T. 2012. The tectonics of China: data, maps and evolution. Springer Science \& Business Media

Wang $\mathrm{Y}$, Cheng $\mathrm{H}$, Edwards RL, Kong X, Shao X, Chen S, Wu J, Jiang X, Wang X, An Z. 2008. Millennial- and orbital-scale changes in the East Asian monsoon over the past 224,000 years. Nature 451: $1090-3$

Wang Y, Fan W, Zhang G, Zhang Y. 2013. Phanerozoic tectonics of the South China Block: Key observations and controversies. Gondwana Research 23: 1273-1305. DOI: 10.1016/j.gr.2012.02.019

Wang Y, Zheng J, Zhang W, Li S, Liu X, Yang X, Liu Y. 2012. Cenozoic uplift of the Tibetan Plateau: Evidence from the tectonic-sedimentary evolution of the western Qaidam Basin. Geoscience Frontiers 3: 175-187

Wray RAL. 2013. Solutional Weathering and Karstic Landscapes on Quartz Sandstones and Quartzite. Shroder J (ed). Elsevier Ltd.; 463-483.

Wu C, Zhang C. 2002. The Form and Evolvement of the Physiognomy of the Beauty Spot in Zhangjiajie. Geography and Territorial Research 18: 53-55

Wu G. 2005. The Yanshanian Orogeny and Two Kinds of Yanshanides in Eastern Central China. Acta Geologica Sinica 79: 507-518

Yang G, Tian M, Zhang X, Chen Z, Wray RaL, Ge Z, Ping Y, Ni Z, Yang Z. 2012. Quartz sandstone peak forest landforms of Zhangjiajie Geopark, northwest Hunan Province, China: pattern, constraints and comparison. Environmental Earth Sciences 65: 1877-1894. DOI: 10.1007/s12665-011-1170-1

Yang G, Yang Z, Zhang X, Tian M, Chen A, Ge Z, Ping Y, Ni Z. 2011a. RS-based geomorphic analysis of Zhangjiajie Sandstone Peak Forest Geopark, China. Journal of Cultural Heritage 12: 88-97 
Yang G, Zhang X, Tian M, Brierley G, Chen A, Ping Y, Ge Z, Ni Z, Yang Z. 2011b. Alluvial terrace systems in Zhangjiajie of northwest Hunan, China: Implications for climatic change, tectonic uplift and geomorphic evolution. Quaternary International 233: $27-39$

Yang G, Zhang X, Tian M, Ping Y, Chen A, Ge Z, Ni Z, Yang Z. 2010. Geomorphological and sedimentological comparison of fluvial terraces and karst caves in Zhangjiajie, northwest Hunan, China: an archive of sandstone landform development. Environmental Earth Sciences 64: 671-683

Yao X-Y, Yin H-G. 2011. An Analysis on the Impact of Movie Marketing on Tourists' Decision-Making: A Case Study of Zhangjiajie Leveraged by "Avatar". Geography and Geo-Information Science 4: 22

Young RW. 2009. Bungle Bungle: Tower karst in Sandstone. In Geomorphological Landscapes of the World. Springer; 333-340.

Young RW, Wray RA. 2015. Rock control in sandstone geomorphology: a tribute to Eiju Yatsu with some Australian examples. Zeitschrift für Geomorphologie 59, Suppl 1: 3-17

Young RW, Wray RAL, Young ARM. 2009. Sandstone Landforms. Cambridge University Press: Cambridge

Zhao X, Wang M. 2002. National geoparks initiated in China: Putting geoscience in the service of society. Episodes 25: 33-37

Zhao X, Wu ZH, Wu ZH, Zhao D. 2011. Geomorphologic and Geologic Characteristics of Zhangjiajie and the Formation Mechanism of Geologic Landscape. Geologic Publishing House: Beijing

Zheng MG. 2014. Recent change of runoff and its components of baseflow and surface runoff in response to climate change and human activities for the Lishui watershed of southern China. In Dynamic Processes of Zhangjiajie Landform Evolution (Final Report), Shi CX, Qi DL, Zheng MG, Sun LY, Fang HY, He L, Yan YX, Wang SJ, Yan M (eds). Institute of Geographic Sciences and Natural Resources Research, Chinese Academy of Sciences and Management Committee of Zhangjiajie Global Geopark, Hunan Province: Beijing; 10-34.

Zheng YF, Xiao WJ, Zhao G. 2013. Introduction to tectonics of China. Gondwana Research 23: 1189-1206. DOI: 10.1016/j.gr.2012.10.001

Zhou X-J, Xia W-S, Tan C-Y. 2004. The Mechanism of Forming the Physiognomy in Jinbianqi and its Process of Evolvement - Recognition of Physiognomy of Zhangjiajie. Jour. Nat. Scie. Hunan Norm. Univ. 27: 95-97 


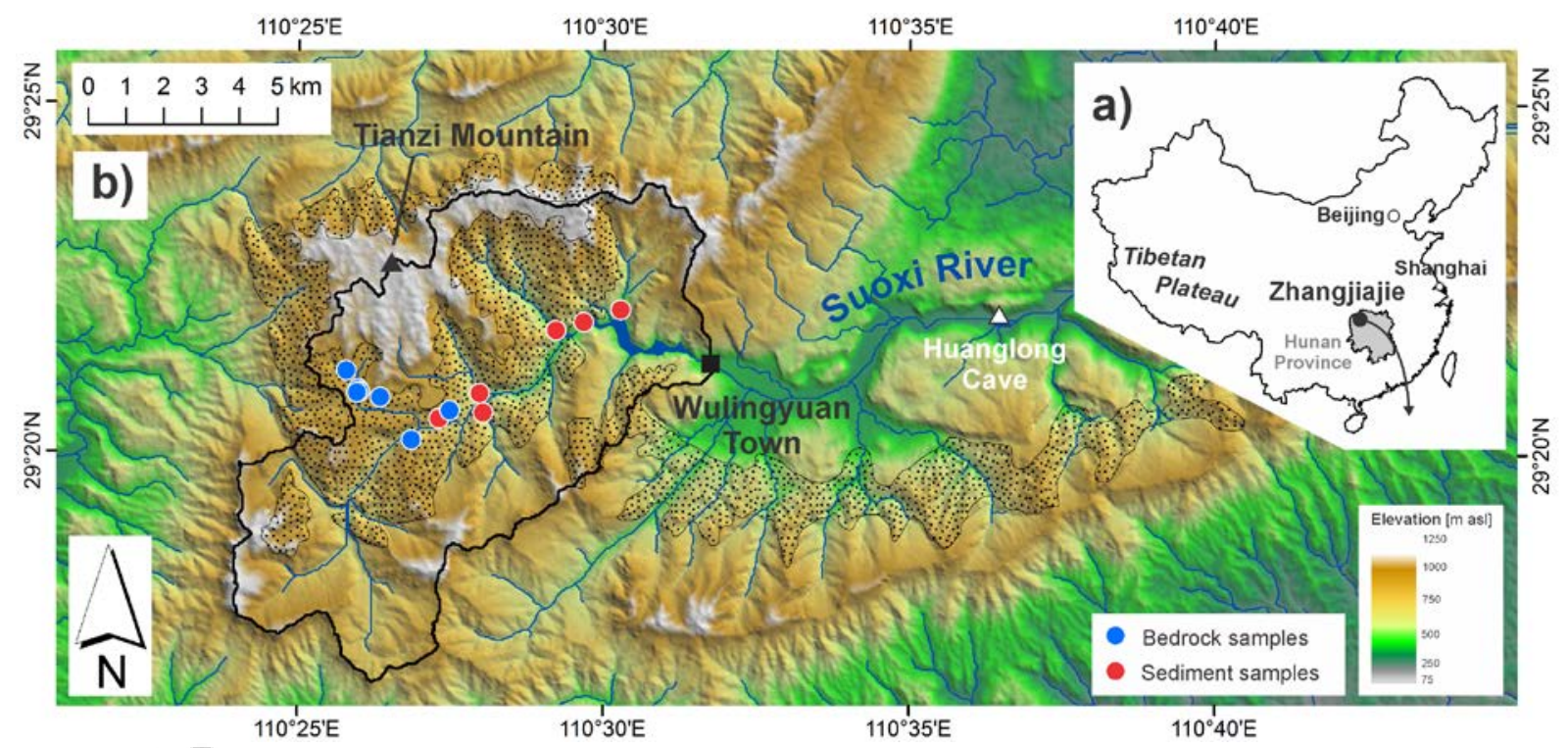

Fig. 1: Overview of the study area. a) Location of Zhangjiajie Global Geopark in China. b) Geographic setting and topography (SRTM data) of the upper Suoxi River catchment (black line) at Wulingyuan Town of Zhangjiajie City, and the regional distribution of sandstone peak-forest areas (black dotted area) characterized by sandstone pillars, peak walls and peak clusters (modified from Yang et al., 2012). Red and blue symbols denote locations of sediment and bedrock samples for cosmogenic nuclide analyses, respectively. 


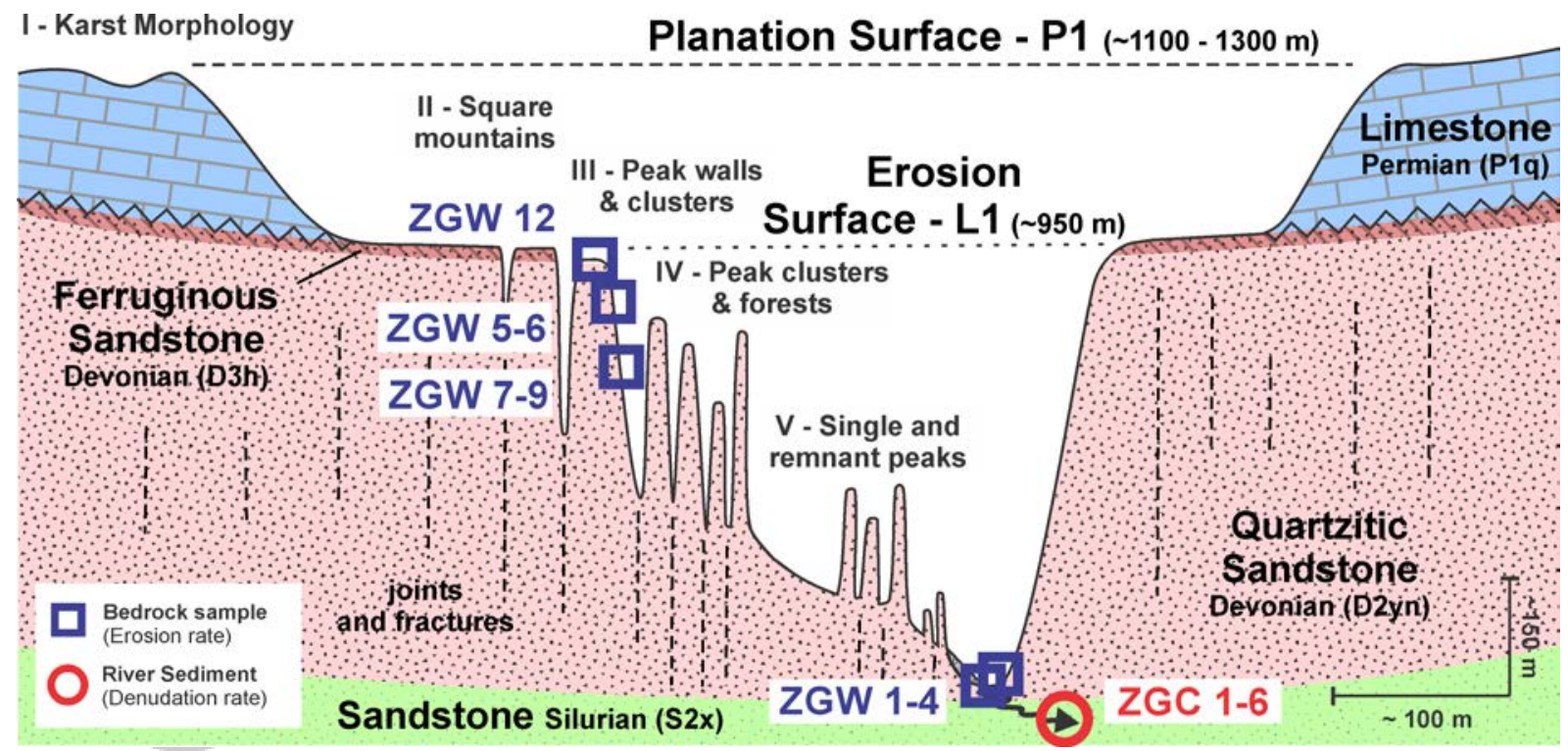

Fig. 2: Generalized geomorphic and geological cross-section in vicinity of Tianzi Mountain in the upper Suoxi catchment in relation to a conceptual model of sandstone peak-forest formation. Squares and circles illustrate the locations of cosmogenic nuclide samples (ZGW are bedrock samples, ZGC are river sediments for catchment-wide denudation rates) in the vertical sequence of landforms. Labels I to $\mathrm{V}$ represent the sequential process in the evolution of the sandstone peaks. Zigzag line indicates an erosional unconformity between Devonian and Permian strata.

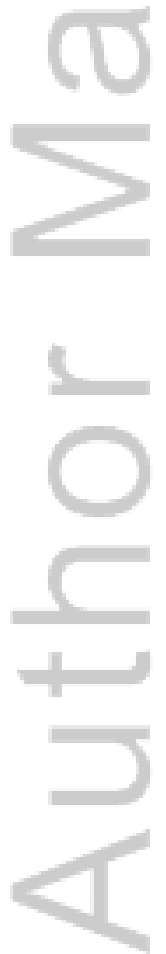

This article is protected by copyright. All rights reserved. 

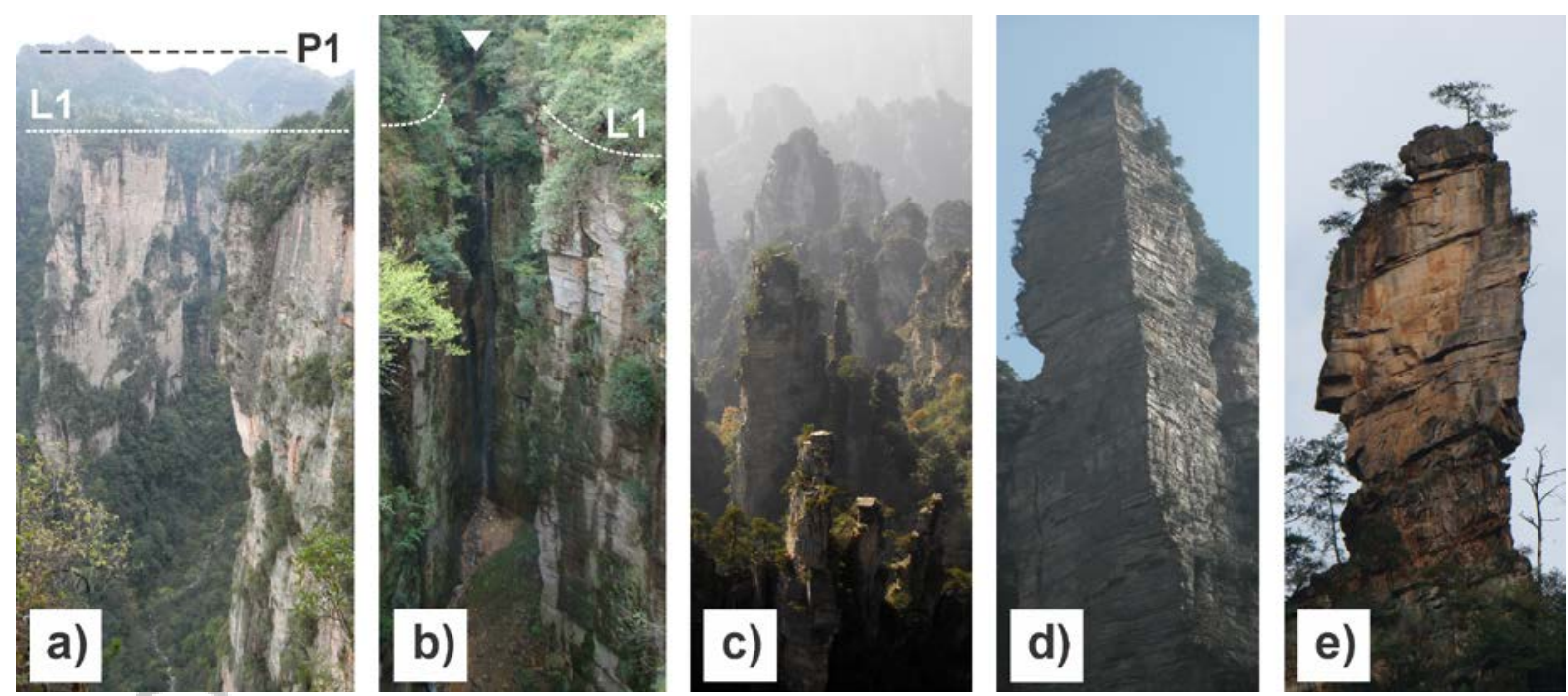

Fig. 3: Photographs of the key regional sandstone landforms in the study area. a) Upper planation surface (P1) at $\sim 1300 \mathrm{~m}$ asl of the karst morphology associated with Permian limestone, capping an upper erosion surface (L1) between $\sim 900-1000 \mathrm{~m}$ asl, of Devonian quartzitic sandstone (D2yn) which is exposed as square mountains and peak walls with vertical drops of up to $\sim 300 \mathrm{~m} \mathrm{~b}$ ) Small waterfall (triangle denotes plunge point) in a valley head associated with erosion surface L1; c) Sandstone peak clusters and forest forms of decreasing height and elevation; d) "Golden Whip" sandstone tower with sharp and rectangular walls associated with the intersection of two major fracture or joint lines); e) Single remnant pillar at the margin of well-developed sandstone peak-forest landforms (note inclination of bedding planes of $230^{\circ}$ ).

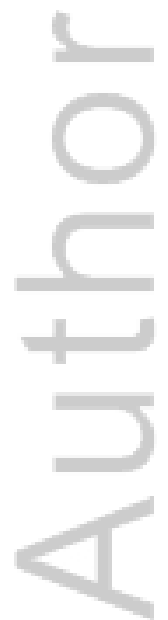



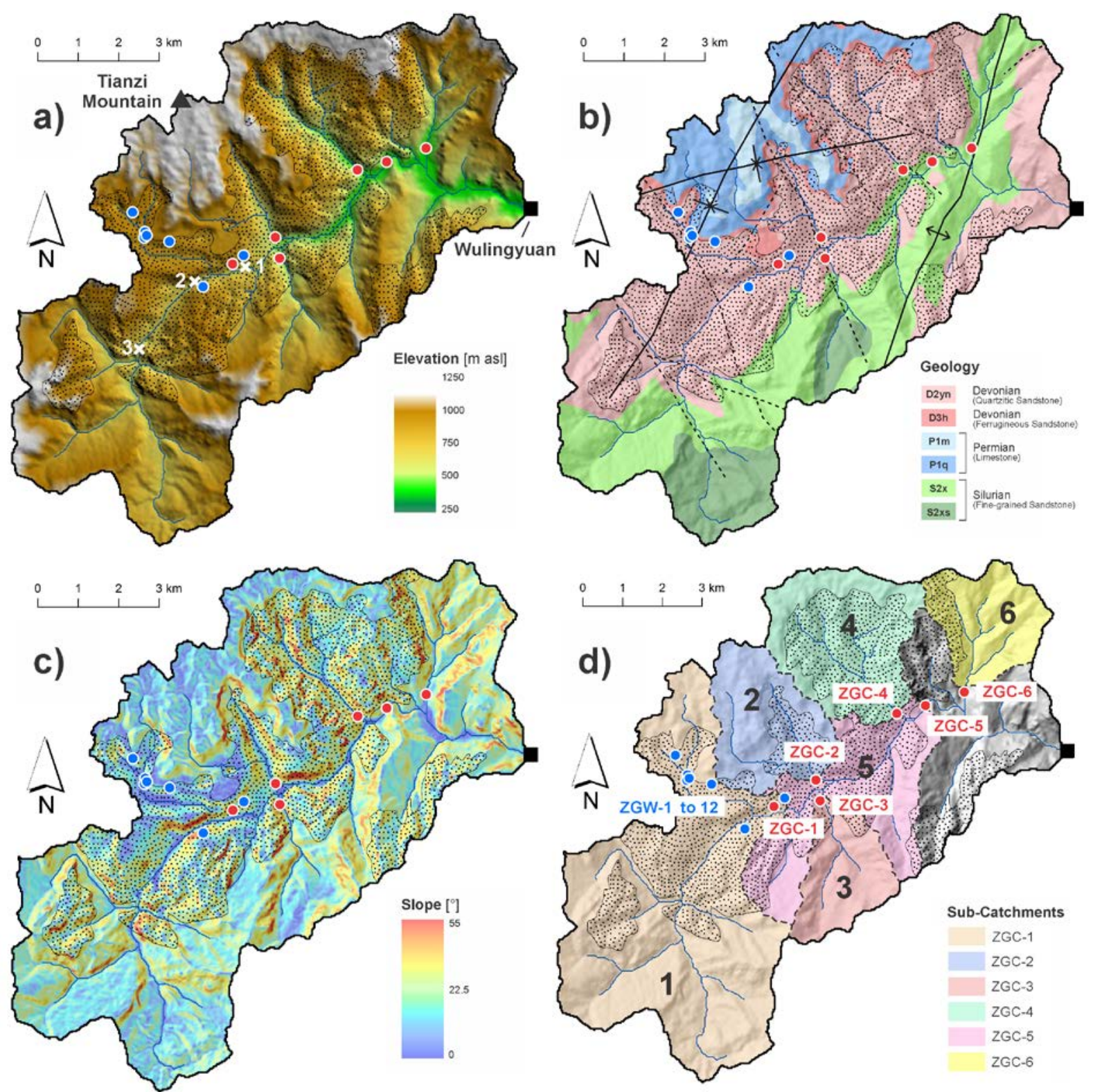

Fig. 4: Geomorphic setting of the study area, location of samples (blue dots = bedrock samples, red dots = river sediment) and valley cross-sections (white crosses, see Fig. 5); stippled areas show the regions of sandstone peak-forest landforms (modified from Yang et al. 2012). a) Overview of the upper Suoxi catchment upstream of Wulingyuan Town illustrating the distribution of topography; $b$ ) Geology (dashed lines are major fractures and black lines are synclines/anticlines; modified from Yang et al. 2012); c) Slope (based on SRTM-1 arc DEM); d) Subcatchments for each river sediment sample. Note that sub-catchment ZGC-5 also includes the upstream area represented by ZGC-1 to 4. 


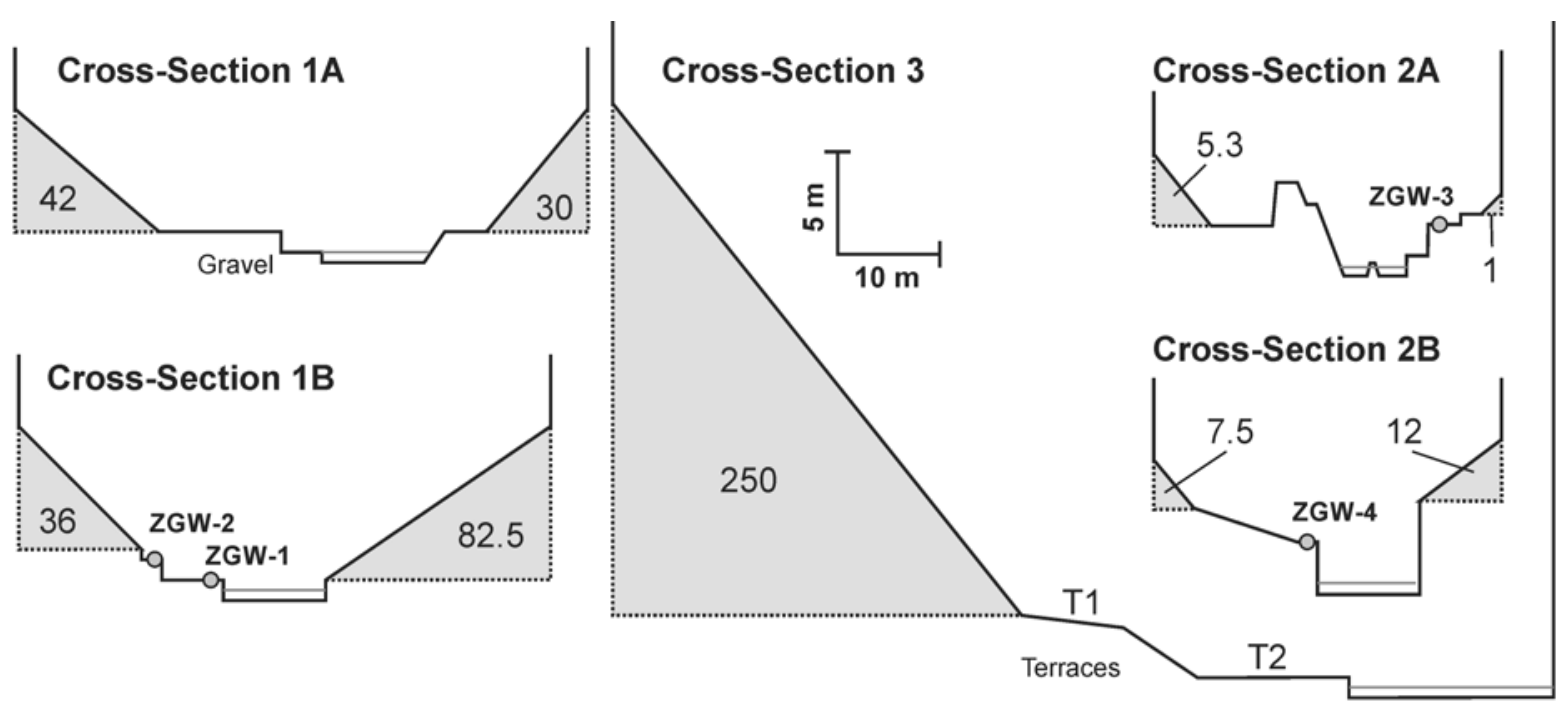

Fig. 5: Cross-sectional profiles along the upper Suoxi River illustrating the existence of colluvial cones of coarse-grained sandstone debris (grey) as the result of rock fall and weathering products from the hanging vertical walls accumulating along the channel floor (see Fig. 4a for locations of cross-sections; numbers indicate crosssectional area in $\mathrm{m}^{2}$ of measured cones; ZGW1-4 show locations of samples for exposure dating along bedrock channels).

This article is protected by copyright. All rights reserved. 

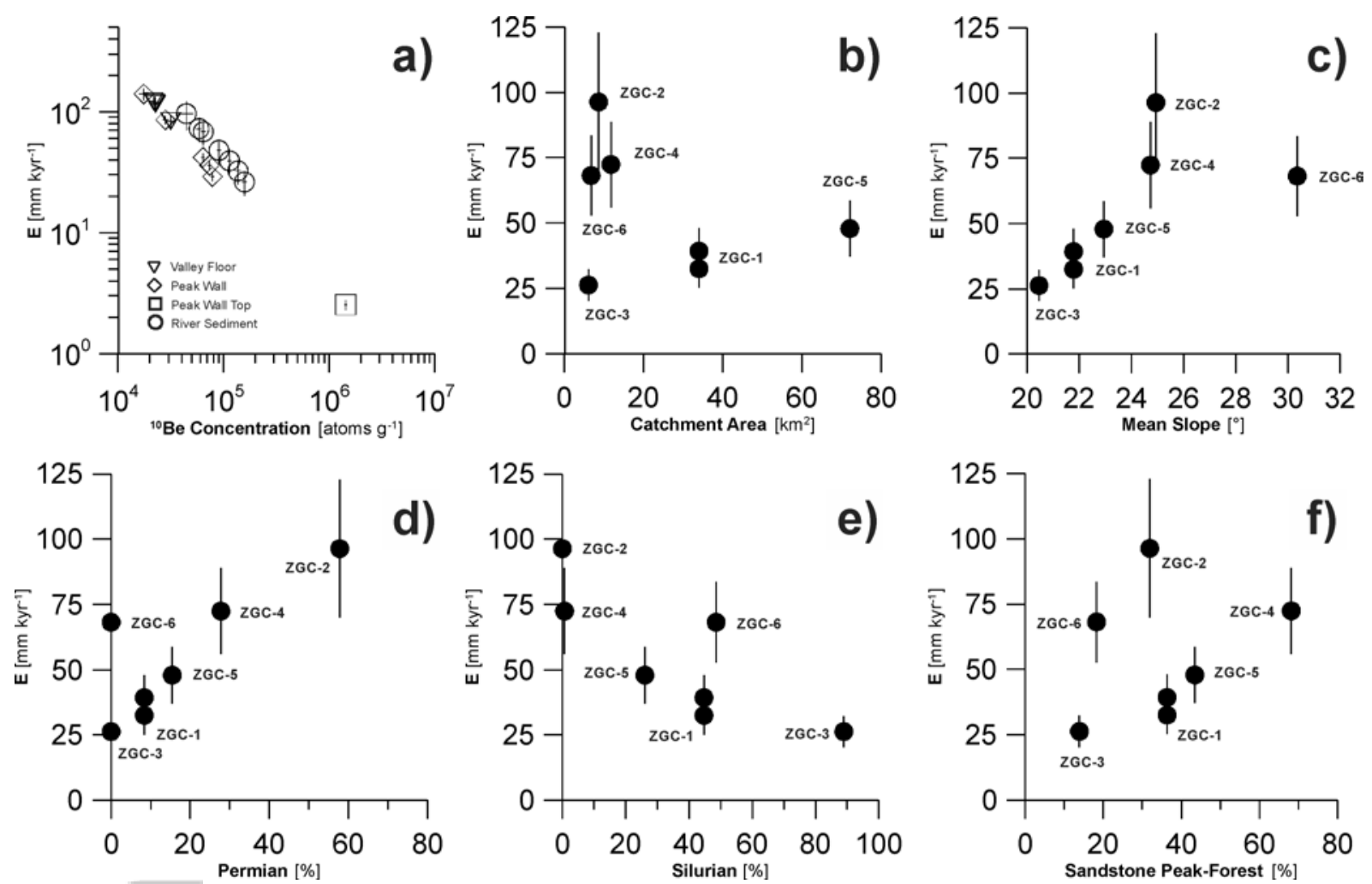

Fig. 6: Results from cosmogenic nuclide analysis expressed in $10 \mathrm{Be}$ concentrations and model erosion rates $E(a)$, and comparison of erosion rates with selected subcatchment characteristics such as catchment area (b), mean slope (c), the area of overlying Permian limestone (d) and underlying Silurian sandstone (e), and the area occupied by sandstone peak-forest landforms in each sub-catchment (f). Note that sub-catchment ZGC-5 also includes the upstream area represented by ZGC-1 to 4 . 


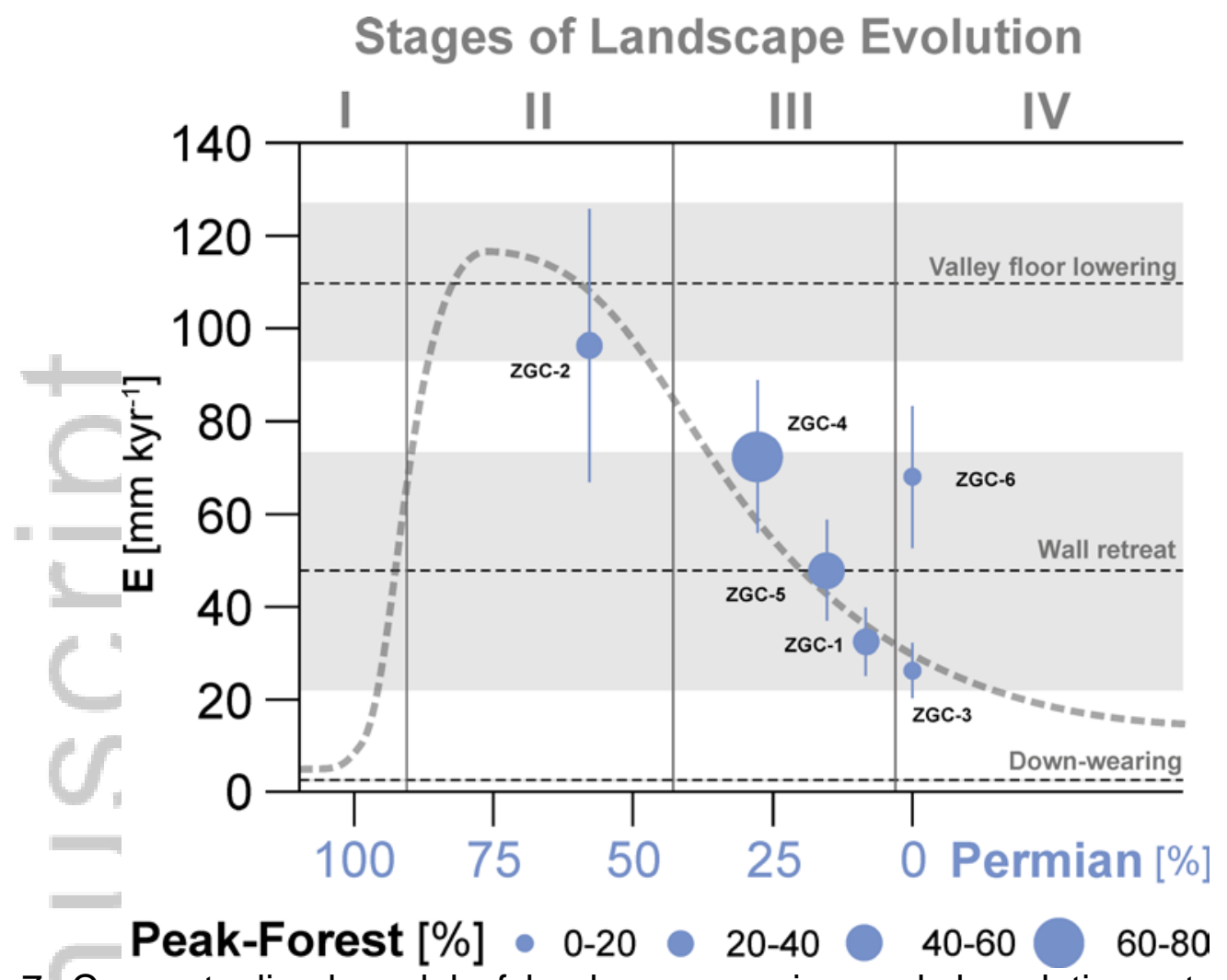

Fig. 7: Conceptualized model of landscape erosion and denudation rates (dashed curve) during the successive stages I to IV in the formation and decay of sandstone peak-forest landscapes at Zhangjiajie. Dots mark the position of the sampled subcatchments in this sequence as defined by denudation rate, and relative time as reflected by remaining area covered by overlying Permian limestone, size of dots indicates the area of peak-forest per sub-catchment (see text for details). Note that sub-catchment ZGC-5 also includes the upstream area represented by ZGC-1 to 4 . Thin dashed lines with grey boxes indicate valley lowering $\left(110 \pm 17 \mathrm{~mm} \mathrm{kyr}^{-1}\right)$, vertical wall retreat $\left(48 \pm 26 \mathrm{~mm} \mathrm{kyr}^{-1}\right)$, and peak top lowering $(\sim 3 \mathrm{~mm} \mathrm{kyr})$ rates with associated $1 \sigma$ uncertainty. 
Table 1: River sediment sample locations and upstream catchment morphometrics derived from SRTM 1 arc DEM and geological data in Yang et al. 2012

\begin{tabular}{|c|c|c|c|c|c|c|c|c|c|c|c|c|c|c|}
\hline Sub-Catchment & Lat $\left[{ }^{\circ} \mathrm{N}\right]^{\mathrm{a}}$ & Long $\left[^{\circ} E\right]^{a}$ & $\begin{array}{l}\text { GPS Elevation } \\
\text { [m asl] }\end{array}$ & \begin{tabular}{|l|} 
Area \\
{$\left[\mathrm{km}^{2}\right]$}
\end{tabular} & $\begin{array}{l}\text { Max. Elevation } \\
{[\mathrm{m} \text { asl] }}\end{array}$ & \begin{tabular}{|l} 
Min. Elevation \\
[m asl]
\end{tabular} & $\begin{array}{l}\text { Total Relief } \\
{[\mathrm{m}]}\end{array}$ & $\begin{array}{l}\text { Mean Elevation } \\
{[\mathrm{m} \text { asl] }}\end{array}$ & \begin{tabular}{|l|} 
Mean Slope \\
{$\left[{ }^{\circ}\right]$}
\end{tabular} & $\begin{array}{l}\begin{array}{l}\text { Silurian } \\
\text { [\%] }\end{array} \\
\end{array}$ & $\begin{array}{l}\text { Devonian } \\
\text { [\%] }\end{array}$ & $\begin{array}{l}\text { Permian } \\
{[\%]}\end{array}$ & $\begin{array}{l}\mathrm{D}_{2} \mathrm{yn}^{\mathrm{b}} \\
{[\%]}\end{array}$ & $\begin{array}{l}\text { Peak-Forest }{ }^{\mathrm{c}} \\
{[\%]}\end{array}$ \\
\hline ZGC-1 & 29.34139 & 110.45528 & 493 & 33.99 & 1237 & 577 & 660 & 870 & 21.8 & 45 & 47 & 8 & 45 & 36 \\
\hline ZGC-2 & 29.34750 & 110.46611 & 496 & 8.64 & 1186 & 487 & 699 & 945 & 24.9 & 0 & 42 & 58 & 29 & 32 \\
\hline ZGC-3 & 29.34278 & 110.46722 & 486 & 6.04 & 1158 & 496 & 662 & 780 & 20.5 & 89 & 11 & 0 & 11 & 14 \\
\hline ZGC-4 & 29.36250 & 110.48694 & 448 & 11.72 & 1262 & 429 & 833 & 879 & 24.7 & 1 & 72 & 28 & 60 & 68 \\
\hline$Z G C-5^{d}$ & 29.36444 & 110.49444 & 447 & 72.14 & 1262 & 404 & 858 & 851 & 22.9 & 26 & 48 & 15 & 44 & 43 \\
\hline ZGC-6 & 29.36750 & 110.50444 & 390 & 6.71 & 1260 & 403 & 857 & 845 & 30.4 & 49 & 51 & 0 & 51 & 18 \\
\hline Wulingyuan & 29.35444 & 110.53083 & 342 & 90.08 & 1262 & 342 & 926 & 826 & 24.2 & 37 & 51 & 12 & 47 & 41 \\
\hline
\end{tabular}

a) Measured using a hand-held GPS unit. Coordinates are referenced to WGS84.

b) Percentage of catchment area with Middle Devonian Yuntaiguan Formation

c) Percentage of catchment area with Middle Devonian Yuntaitchment area with peak-forest landforms

d) Note that the catchment for ZGC-5 includes catchments ZGC-1 to 4; morphometrics for ZGC-5 therefore integrate over ZGC-1 to 4 plus the area labelled as ZGC-5 in Fig. $4 \mathrm{~d}$

(a)

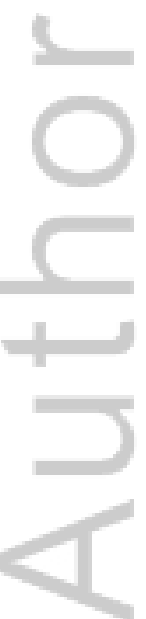

This article is protected by copyright. All rights reserved. 
Table 2: Results from cosmogenic nuclide analysis of bedrock samples

\begin{tabular}{|c|c|c|c|c|c|c|c|c|c|c|c|}
\hline $\begin{array}{l}\text { Sample } \\
\text { Name }\end{array}$ & Lat $\left[{ }^{\circ} \mathrm{N}\right]^{\mathrm{a}}$ & Lon $\left[{ }^{\circ} \mathrm{E}\right]^{\mathrm{a}}$ & $\begin{array}{l}\text { Elevation }^{a} \\
{[\mathrm{~m} \text { asl] }}\end{array}$ & $\begin{array}{c}\text { Height above } \\
\text { channel floor } \\
{[\mathrm{m}]}\end{array}$ & $\begin{array}{l}\text { Topographic } \\
\text { Shielding } \\
\text { Factor }\end{array}$ & $\begin{array}{l}\text { Quartz } \\
\text { mass } \\
\text { (g) }\end{array}$ & $\begin{array}{c}\mathrm{Be} \\
\text { carrier } \\
(\mu \mathrm{g}) \\
\end{array}$ & $\begin{array}{c}{ }^{10} \mathrm{Be}^{9}{ }^{-} \mathrm{Be}^{\mathrm{b}} \\
\left(10^{-15}\right)\end{array}$ & $\begin{array}{l}{ }^{10} \text { Be Concentration }\left(10^{3}\right. \\
\left.\text { atoms. } g^{-1}\right)\end{array}$ & Erosion Rate ${ }^{\mathrm{c}}\left(\mathrm{mm} \cdot \mathrm{kyr}^{-1}\right)$ & $\begin{array}{c}\text { Averaging } \\
\text { Timescale }^{\mathrm{d}}(\mathrm{kyr})\end{array}$ \\
\hline ZGW-1 & 29.34336 & 110.45811 & 467.7 & $\sim 1.2$ & 0.6764 & 30.874 & 324.3 & $30.7 \pm 1.8$ & $21.6 \pm 1.4$ & $122 \pm 11$ & 15 \\
\hline ZGW-2 & 29.34336 & 110.45811 & 467.7 & $\sim 1.8$ & 0.6764 & 30.751 & 326.8 & $31.9 \pm 3.9$ & $22.7 \pm 2.8$ & $116 \pm 17$ & 15 \\
\hline ZGW-3 & 29.33639 & 110.44771 & 475.0 & $\sim 1.1$ & 0.6833 & 30.053 & 326.5 & $30.7 \pm 3.2$ & $22.3 \pm 2.4$ & $119 \pm 15$ & 15 \\
\hline ZGW-4 & 29.33639 & 110.44771 & 475.0 & $\sim 2.0$ & 0.6833 & 30.077 & 327.2 & $43.3 \pm 4.3$ & $31.5 \pm 3.2$ & $83 \pm 10$ & 21 \\
\hline ZGW-5 & 29.34856 & 110.43292 & 957.9 & $\sim 350$ & 0.4999 & 60.089 & 326.2 & $175.5 \pm 6.6$ & $63.7 \pm 2.8$ & $42 \pm 3$ & 42 \\
\hline ZGW-6 & 29.34856 & 110.43292 & 957.9 & $\sim 340$ & 0.4999 & 60.116 & 326.6 & $202.5 \pm 7.8$ & $73.5 \pm 3.3$ & $36 \pm 3$ & 51 \\
\hline ZGW-7 & 29.35285 & 110.42977 & 922.7 & $\sim 280$ & 0.4262 & 60.248 & 327.0 & $216.8 \pm 7.3$ & $78.6 \pm 3.2$ & $29 \pm 2$ & 63 \\
\hline ZGW-8 & 29.35285 & 110.42977 & 922.7 & $\sim 280$ & 0.4262 & 60.228 & 328.2 & $48.2 \pm 4.5$ & $17.6 \pm 1.7$ & $140 \pm 16$ & 15 \\
\hline ZGW-9 & 29.35285 & 110.42977 & 922.7 & $\sim 280$ & 0.4262 & 60.118 & 326.3 & $77.6 \pm 3.9$ & $28.2 \pm 1.6$ & $86 \pm 7$ & 21 \\
\hline ZGW-12 & 29.34640 & 110.43910 & 917.5 & -370 & 0.9820 & 30.899 & 325.7 & $2037.9 \pm 24.7$ & $1435.4 \pm 36.5$ & $3 \pm 0.2$ & 720 \\
\hline
\end{tabular}

Sample thickness was $4 \mathrm{~cm}$ for all samples. Uncertainties expressed at the 1-sigma level.

a) Measured using a hand-held GPS unit. Coordinates are referenced to WGS84.

b) Measured by AMS. ${ }^{10} \mathrm{Be} /{ }^{9} \mathrm{Be}$ ratios were normalised to $2007 \mathrm{KNSTD}$ standard KN-5-2 (Nishiizumi et al., 2007) and corrected for a mean procedural blank with ${ }^{10} \mathrm{Be} /{ }^{9} \mathrm{Be}=5.80 \pm 1.39 \times 10^{-15}(\mathrm{n}=5$, mean of 2 targets)

c) Calculated using CRONUS-Earth calculator v. 2.3 (Balco et al., 2008; http://hess.ess.washington.edu).

d) Time required for the measured ${ }^{10} \mathrm{Be}$ cosmogenic nuclide concentration to reach steady-state (or equilibrium) conditions and thus represent the bedrock erosion rate, i.e. this equates to the time required to erode at least three attenuation lengths of rock; i.e. $\sim 3 \times 60 \mathrm{~cm}$ derived from a neutron spallation attenuation length of $160 \mathrm{~g} \mathrm{~cm}^{-2}$ and a density of $2.7 \mathrm{~g} \mathrm{~cm}^{-3}$ (Lal 1991 ).

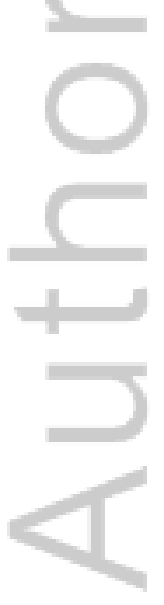

This article is protected by copyright. All rights reserved. 
Table 3: Results from cosmogenic nuclide analysis of river sediment

\begin{tabular}{|c|c|c|c|c|c|c|c|c|c|c|c|}
\hline Name & Lat $\left[{ }^{\circ} \mathrm{N}\right]^{\mathrm{a}}$ & Lon $\left[{ }^{\circ} E\right]^{a}$ & $\begin{array}{c}\text { Avg. } \\
\text { Production Rate } \\
\text { Scaling }\end{array}$ & $\begin{array}{l}\text { Avg. } \\
\text { Topographic } \\
\text { Shielding }^{\mathrm{b}}\end{array}$ & $\begin{array}{l}\text { Avg. } \\
\text { Combined } \\
\text { Scaling }{ }^{b}\end{array}$ & $\begin{array}{l}\text { Quartz } \\
\text { (g) }\end{array}$ & $\begin{array}{l}\text { Be carrier } \\
\quad(\mu \mathrm{g})\end{array}$ & $\begin{array}{c}{ }^{10} \mathrm{Be}^{9}{ }^{9} \mathrm{Be}^{\mathrm{c}} \\
\left(10^{-15}\right)\end{array}$ & $\begin{array}{c}{ }^{10} \text { Be Concentration } \\
\left(10^{3} \text { atoms. } g^{-1}\right)\end{array}$ & $\begin{array}{l}\text { Average Basin } \\
\text { Denudation Rate } \\
\left(\mathrm{mm} \cdot \mathrm{kyr}^{-1}\right)\end{array}$ & $\begin{array}{l}\text { Averaging } \\
\text { Timescale }^{\mathrm{d}} \\
\text { (kyr) }\end{array}$ \\
\hline ZGC-1(III)* & 29.34080 & 110.45825 & 1.5671 & 0.9702 & 1.5214 & 41.087 & 325.1 & $215.0 \pm 9.2$ & $113.7 \pm 5.5$ & $39 \pm 9$ & 45 \\
\hline ZGC-1(IV) $)^{\star \star}$ & 29.34080 & 110.45825 & 1.5671 & 0.9702 & 1.5214 & 27.993 & 328.0 & $174.5 \pm 9.2$ & $136.6 \pm 7.8$ & $33 \pm 7$ & 60 \\
\hline ZGC-2 & 29.34759 & 110.46687 & 1.4736 & 0.9618 & 1.4192 & 15.166 & 327.8 & $30.7 \pm 4.8$ & $44.3 \pm 7.0$ & $96 \pm 30$ & 20 \\
\hline ZGC-3 & 29.34299 & 110.46782 & 1.4828 & 0.9551 & 1.4169 & 9.740 & 327.5 & $70.1 \pm 3.5$ & $157.5 \pm 8.6$ & $26 \pm 6$ & 75 \\
\hline ZGC-4 & 29.36204 & 110.48812 & 1.4930 & 0.9434 & 1.4117 & 30.513 & 328.4 & $81.3 \pm 3.7$ & $58.5 \pm 3.0$ & $72 \pm 17$ & 25 \\
\hline ZGC-5 & 29.36504 & 110.49428 & 1.5173 & 0.9615 & 1.4609 & 30.657 & 328.6 & $126.2 \pm 5.7$ & $90.4 \pm 4.6$ & $48 \pm 11$ & 40 \\
\hline ZGC-6 & 29.36759 & 110.50447 & 1.5610 & 0.9385 & 1.4679 & 30.230 & 328.6 & $88.4 \pm 4.3$ & $64.2 \pm 3.4$ & $68 \pm 15$ & 30 \\
\hline
\end{tabular}

Uncertainties expressed at the 1-sigma level. *- pebble size, ${ }^{* *}$ - sand size.

a) Coordinates are referenced to WGS84 and represent the locations of the catchment outlets on the SRTM 1arc DEM. Note that these are not the same as the coordinates listed in Table 1.

b) Calculated using CAIRN (Mudd et al., 2016) using the SRTM 1arc DEM.

c) Measured by AMS. ${ }^{10} \mathrm{Be} /{ }^{9} \mathrm{Be}$ ratios were normalised to $2007 \mathrm{KNSTD}$ standard $\mathrm{KN}-5-2$ (Nishiizumi et al., 2007), and corrected for a mean procedural blank with ${ }^{10} \mathrm{Be} /{ }^{9} \mathrm{Be}=5.80 \pm 1.39 \times 10^{-15}$ ( $n=5$, mean of 2 targets).

d) Time required for the measured ${ }^{10} \mathrm{Be}$ cosmogenic nuclide concentration to reach steady-state (or equilibrium) conditions and thus represent the average catchment-wide denudation rate (Lal 1991).

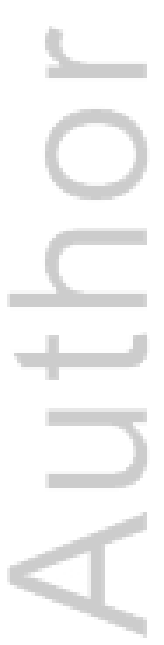

This article is protected by copyright. All rights reserved. 
Table 4: Combined results from GIS and cosmogenic nuclide analysis, and estimated timeframes for the onset of sandstone peak-forest formation at Zhangjiajie.

\begin{tabular}{|c|c|c|c|c|c|c|c|c|c|c|c|}
\hline $\begin{array}{l}\text { Sub- } \\
\text { Catchments }\end{array}$ & $\begin{array}{c}\text { Volume } \\
\text { SRTM-1arc } \\
{\left[\mathrm{km}^{3}\right]}\end{array}$ & $\begin{array}{c}\text { Volume } \\
\text { SRTM-3arc } \\
{\left[\mathrm{km}^{3}\right]}\end{array}$ & $\begin{array}{c}\text { Volume } \\
\text { Aster GDEM } \\
{\left[\mathrm{km}^{3}\right]}\end{array}$ & $\begin{array}{c}\text { Volume } \\
\text { ALOS } \\
{\left[\mathrm{km}^{3}\right]}\end{array}$ & $\begin{array}{c}\text { Avg. } \\
\text { Denudation } \\
\text { Volume } \\
{\left[\mathrm{km}^{3}\right]} \\
\end{array}$ & $\begin{array}{c}\text { Avg. } \\
\text { Denudation } \\
\text { Surface } \\
{\left[\mathrm{km}^{2}\right]} \\
\end{array}$ & $\begin{array}{l}\text { Avg. Denudation } \\
\text { Thickness } \\
{[\mathrm{m}]}\end{array}$ & $\begin{array}{c}\text { Max. Fluvial } \\
\text { Incision Depth }{ }^{\text {a }} \\
{[\mathrm{m}]}\end{array}$ & $\begin{array}{c}\text { Avg. Time }{ }^{\mathrm{c}} \\
\text { [Ma] } \\
\text { (Scenario I) }\end{array}$ & $\begin{array}{l}\text { Avg. Time }{ }^{d} \\
{[\text { Ma] }} \\
\text { (Scenario II) }\end{array}$ & $\begin{array}{l}\text { Avg. Unit Erosion } \\
\text { Rate }^{\mathrm{b}} \\
{\left[\mathrm{t} \mathrm{km}^{-2} \mathrm{yr}^{-1}\right]}\end{array}$ \\
\hline ZGC-1 & 3.54 & 3.20 & 4.13 & 3.64 & $3.63 \pm 0.59$ & $23.56 \pm 1.93$ & $153.0 \pm 12.6$ & $457 \pm 25$ & $4.15 \pm 0.68$ & $4.71 \pm 1.21$ & $87.8 \pm 19.7$ \\
\hline ZGC-2 & 0.59 & 0.38 & 0.63 & 0.58 & $0.54 \pm 0.10$ & $4.08 \pm 0.24$ & $132.3 \pm 17.1$ & $463 \pm 25$ & $4.21 \pm 0.69$ & $1.37 \pm 0.47$ & $260.3 \pm 79.9$ \\
\hline ZGC-3 & 1.06 & 1.01 & 1.15 & 1.04 & $1.06 \pm 0.13$ & $5.16 \pm 0.15$ & $205.4 \pm 19.0$ & $454 \pm 25$ & $4.13 \pm 0.68$ & $7.81 \pm 2.05$ & $71.0 \pm 16.2$ \\
\hline ZGC-4 & 1.44 & 1.41 & 1.51 & 1.42 & $1.45 \pm 0.17$ & $6.66 \pm 0.38$ & $216.3 \pm 12.6$ & $521 \pm 25$ & $4.74 \pm 0.77$ & $2.99 \pm 0.75$ & $195.5 \pm 44.6$ \\
\hline ZGC-5 & 9.27 & 8.68 & 10.36 & 9.27 & $9.39 \pm 1.27$ & $50.50 \pm 3.08$ & $185.2 \pm 13.8$ & $546 \pm 25$ & $4.96 \pm 0.80$ & $3.87 \pm 0.98$ & $129.3 \pm 29.2$ \\
\hline ZGC-6 & 0.95 & 0.95 & 0.95 & 0.91 & $0.94 \pm 0.11$ & $4.34 \pm 0.26$ & $216.2 \pm 11.9$ & $547 \pm 25$ & $4.97 \pm 0.80$ & $3.18 \pm 0.79$ & $183.9 \pm 41.6$ \\
\hline
\end{tabular}

a) Maximum denudation thickness is the relief between elevation of erosional surface L1 at $\sim 950 \pm 25 \mathrm{~m}$ and the DEM based minimum (channel) elevation per sub-catchment as reported in Table 1 (note that GPS elevation was taken as minimum elevation for ZGC-1 due to the extremely narrow valley cross-section not appropriately reflected in the DEM)

b) Average unit erosion rate was calculated based on a $2.7 \mathrm{~g} \mathrm{~cm}^{-3}$ density as assumed for quartzitic sandstone and the time scale for onset of peak-forest formation based on scenario II.

c) Timeframe calculated based on the average fluvial incision rate (i.e., $110 \pm 17 \mathrm{~mm} \mathrm{kyr}^{-1}$ ).

d) Timeframe calculated from specific catchment-wide averaged denudation rates (Table 3 )

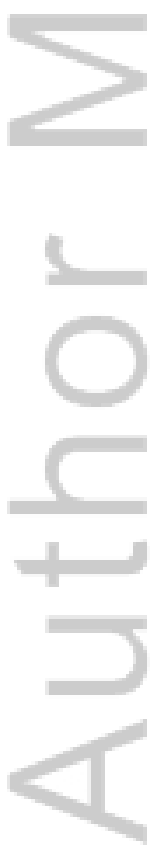

This article is protected by copyright. All rights reserved. 


\section{Graphical Abstract}

In-situ cosmogenic nuclides are used in combination with GIS analysis to investigate the erosional processes contributing to the formation of peak-forests, and discuss their relative roles in the formation and decay of the landscape. Our results suggest that peak-forest formation in Zhangjiajie likely commenced in the Pliocene. and followed our new conceptual model that accounts for the key role of wall retreat processes in the evolution of these landscapes.

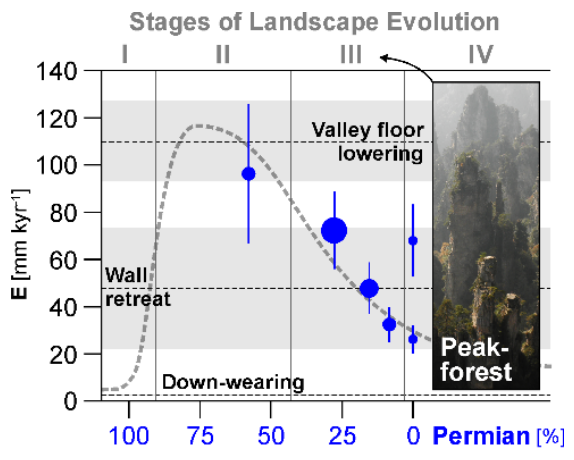

Evolution of sandstone peak-forest landscapes - insights from quantifying erosional processes with cosmogenic nuclides

Jan-Hendrik May*, Huang, He-Qing Huang, Toshiyuki Fujioka, Fink, David Fink, Alexandru Codilean, Guo-An Yu, Yuanxu Ma, Gerwin Wulf and Jing Gu

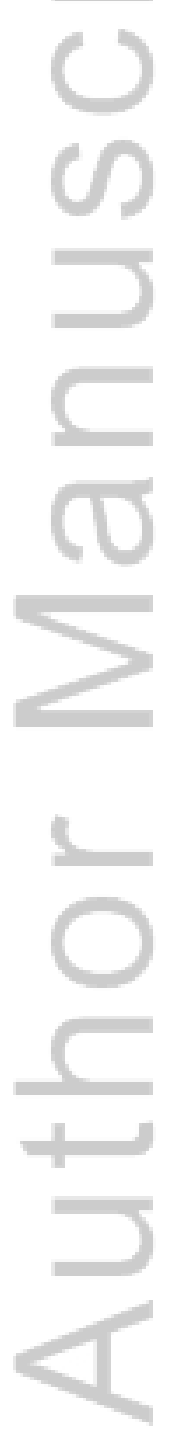

This article is protected by copyright. All rights reserved. 


\section{University Library}

\section{- M M N E R VA A gateway to Melbourne's research publications}

Minerva Access is the Institutional Repository of The University of Melbourne

Author/s:

May, J-H;Huang, H-Q;Fujioka, T;Fink, D;Codilean, A;Yu, G-A;Ma, Y;Wulf, G;Gu, J

Title:

Evolution of sandstone peak-forest landscapes - insights from quantifying erosional processes with cosmogenic nuclides

Date:

2018-03-15

Citation:

May, J. -H., Huang, H. -Q., Fujioka, T., Fink, D., Codilean, A., Yu, G. -A., Ma, Y., Wulf, G. \& $\mathrm{Gu}, \mathrm{J}$. (2018). Evolution of sandstone peak-forest landscapes - insights from quantifying erosional processes with cosmogenic nuclides. Earth Surface Processes and Landforms, 43 (3), pp.639-653. https://doi.org/10.1002/esp.4273.

Persistent Link:

http://hdl.handle.net/11343/293896 